\title{
The challenge of pollen-based quantitative reconstruction of Holocene plant cover in tropical regions: A pilot study in Cameroon
}

Marie-José Gaillard ${ }^{1}$ \& Esther Githumbi ${ }^{1}$

Department of Biology and Environmental Science, Linnaeus University, Kalmar, Sweden

Gaston Achoundong

National Herbarium, IRAD, Yaoundé, Cameroon

Anne-Marie Lézine

Laboratoire d'Océanographie et du Climat, Expérimentation et Approche numérique/IPSL, Sorbonne University, CNRS-IRD-MNHN, Paris, France

Christelle Hély

Institut des Sciences de l'Evolution de Montpellier, Université de Montpellier and Ecole Pratique des Hautes Etudes, Université PSL, Montpellier, France

Judicaël Lebamba

Département de Biologie, Université des Sciences et Techniques de Masuku, Franceville, Gabon

Laurent Marquer ${ }^{2}$

Institute of Botany, University of Innsbruck, Innsbruck, Austria

Florence Mazier

Environmental Geography Laboratory, GEODE UMR-CNRS 5602, Université de Toulouse Jean Jaurès, Toulouse, France

\footnotetext{
${ }^{1}$ Other affiliation: Department of Physical Geography and Ecosystem Science, Lund University, Lund, Sweden ${ }^{2}$ Other affiliation: Research Group for Terrestrial Palaeoclimates, Max Planck Institute for Chemistry, Mainz, Germany
} 


\title{
Furong Li
}

School of Ecology, Sun Yat-sen University, Guangzhou, China

Shinya Sugita

Institute of Ecology, Tallinn University, Estonia

\begin{abstract}
Quantitative pollen-based reconstruction of Holocene plant abundance has not been attempted in the tropics so far. Tropical vegetation is characterized by a large number of entomophilous species and pollen-vegetation modelling for such plants is widely considered too problematic. However, there is a pressing need for quantitative reconstructions of Holocene plant cover in tropical regions to better assess climate- and human-induced environmental crises over time. Of particular note is the environmental crisis at the end of the 'African Humid Period' (c. 3 thousand years before present $[\mathrm{kaBP}]$ ) which remains unquantified. Here, we present results from a pilot study in the Cameroon highlands including estimates of relative pollen productivity (RPP) for major taxa of the Afromontane forests and grasslands using the Extended R-Value (ERV) model, and the first reconstructions of past regional and local Holocene plant cover using the Landscape Reconstruction Algorithm (LRA). RPP estimates were obtained for 12 taxa. We found that Celtis, Alchornea, Syzygium, Macaranga/Mallotus, Nuxia type, and Schefflera have RPPs larger than Poaceae, and Moraceae, Combretaceae/Melastomataceae, Prunus africana/Rubus pinnatus, Cyperaceae, and Podocarpus lower RPPs than Poaceae. The LRA was applied to three Holocene pollen records from Cameroon (Bambili, Mbi, Mbalang) and one from Nigeria (Tilla). The results confirm the abruptness of the forest collapse in Cameroon at $3 \mathrm{ka} \mathrm{BP}$, and suggest that it was faster and of larger magnitude than earlier anticipated. The LRA reconstruction also indicates that the regional landscape in the mountain region was more open than uncorrected pollen percentages alone suggest. Moreover, it supports the earlier interpretation of a dense forest at Bambili 11-3.5 ka BP and the local occurrence of Afromontane forest taxa at Mbalang in the Mid-Holocene.
\end{abstract}

\subsection{INTRODUCTION: THE CHALLENGE}

A way to anticipate the impact of current and future anthropogenic climate change on the environment, in particular in relation to the ongoing '6th extinction' (Barnosky et al. 2011), is to study past crises as accurately as possible. Tropical Africa experienced a major climate-driven environmental crisis at the end of the Holocene (Lézine et al., this volume, and references therein). This crisis affected all natural tropical African ecosystems. Near the equator this resulted in the collapse of Afromontane forests and the expansion of grasslands and woodland grasslands. While in the Sahara and Sahel tropical species disappeared. This crisis is well documented by numerous pollen records acquired over the last decades in western Africa (e.g. Hély et al. 2014; Vincens et al. 1999). However, the resulting land-cover change remains difficult to quantify because of the wide variety of pollen productivity and dispersal mechanisms of tropical plant species (Lézine et al. this volume; Bouimethraan et al., this volume); which implies unexpected and variable representation of the surrounding vegetation by pollen in studies of modern pollen-vegetation relationships (e.g. Gajewski et al. 2002; Julier et al. 2019). The Intergovernmental Panel on Climate Change (IPCC) pointed out that proxy-based climate reconstructions in Africa were too limited to support regional climate change assessments (Masson-Delmotte et al. 2013). In this 
context pollen-based quantification of past land-cover change is essential for climate modelling and the understanding of past land cover-climate interactions (e.g. Gaillard et al. 2010) as they can be used to evaluate Dynamic Vegetation Model simulations (e.g. Lu et al. 2018) and Anthropogenic Land Cover Change scenarios (Kaplan et al. 2017; Li et al. 2020), and help to better evaluate carbon storage over time and its impact on climate.

Quantitative pollen-based reconstruction of Holocene plant abundance have not been attempted in the tropics so far. However, some studies have estimated Relative Pollen Productivity (RPP) of major taxa in tropical and subtropical regions of the world (e.g. Jiang et al. 2020; Wan et al. 2020), including two studies in South Africa (Duffin and Bunting 2008; Hill et al., this volume) and one study in Namibia (Tabares et al. 2021). Here we present results from a pilot study in Cameroon testing methods and models previously used and validated in the northern Hemisphere, i.e. the Extended R-Value (ERV) model (Parsons and Prentice 1981; Prentice and Parsons 1983) and the Landscape Reconstruction Algorithm (LRA; Sugita et al. 2007a and 2007b). The aim was to obtain first estimates of RPPs for major plant taxa and reconstruct their cover over the Holocene at both regional and local spatial scale on the Adamawa Plateau and in the montane/sub-montane regions of Cameroon (Figure 1). Reconstruction of the relationship between the cover of woodland and open land over the $3 \mathrm{ka}$ BP Holocene environmental crisis in Cameroon (e.g. Lézine et al. 2013) is of particular interest and represents a first attempt to quantify the crisis effect on the vegetation cover. We present major results of the study to illustrate the potential of using the ERV model and the LRA in tropical areas, and to highlight major methodological issues and possible improvements.

\subsection{MATERIALS AND METHODS}

\subsubsection{Study Region And Study Sites}

The 30 sites selected for collection of modern soil pollen and related vegetation surveys for the RPP study are distributed at altitudes between 432 and $2990 \mathrm{~m}$ asl. in the montane/submontane and Guineo-Congolian sectors, except one sample at the southern border of the Sudano-Guinean sector (Figure 1, Table S1). A stratified random distribution of sites was chosen to ensure a good representation of the major taxa occurring in the Holocene vegetation history of the study region. However, site distribution was also influenced by logistical issues related to the number and season of the project's field expeditions and other limitations due to local circumstances.

The Holocene pollen sites used for the LRA reconstructions fall within the geographical range of the modern sites and are located at different elevations in the volcanic mountain range of Cameroon, at 2000-2200 m asl. in the Afromontane forest sector (Bambili, Lézine et al. 2013; and Mbi, Lézine et al. 2021), and at 1110-1260 m asl. in the Guineo-Sudanian wooded grasslands (Mbalang, Vincens et al. 2010) (Figures 1, 2; Table S3). An additional pollen site (Tilla, Salzmann et al. 2002) from the Sudanian wooded grassland at $690 \mathrm{~m}$ asl. in Nigeria was selected for the REVEALS reconstruction of regional vegetation needed to apply the LOVE model for reconstruction of the local vegetation around Mbalang (Figure 1; Table S3). For further details on the choice of sites, please see Supporting Online Material (SOM) section 12.2.4. Henceforth, all dates are given in calibrated ${ }^{14} \mathrm{C}$ kyrs before present (CE 1950) (abbreviated ka BP).

\subsubsection{Pollen And Vegetation Data}

The collection of soil samples and vegetation surveys for the RPP study were performed in February 2010, October 2012, and April 2015. The pollen-vegetation dataset includes data from 4 sites in semi-deciduous forests, 10 sites in mountain forests, and 16 sites in savannahs (Figure 1; 


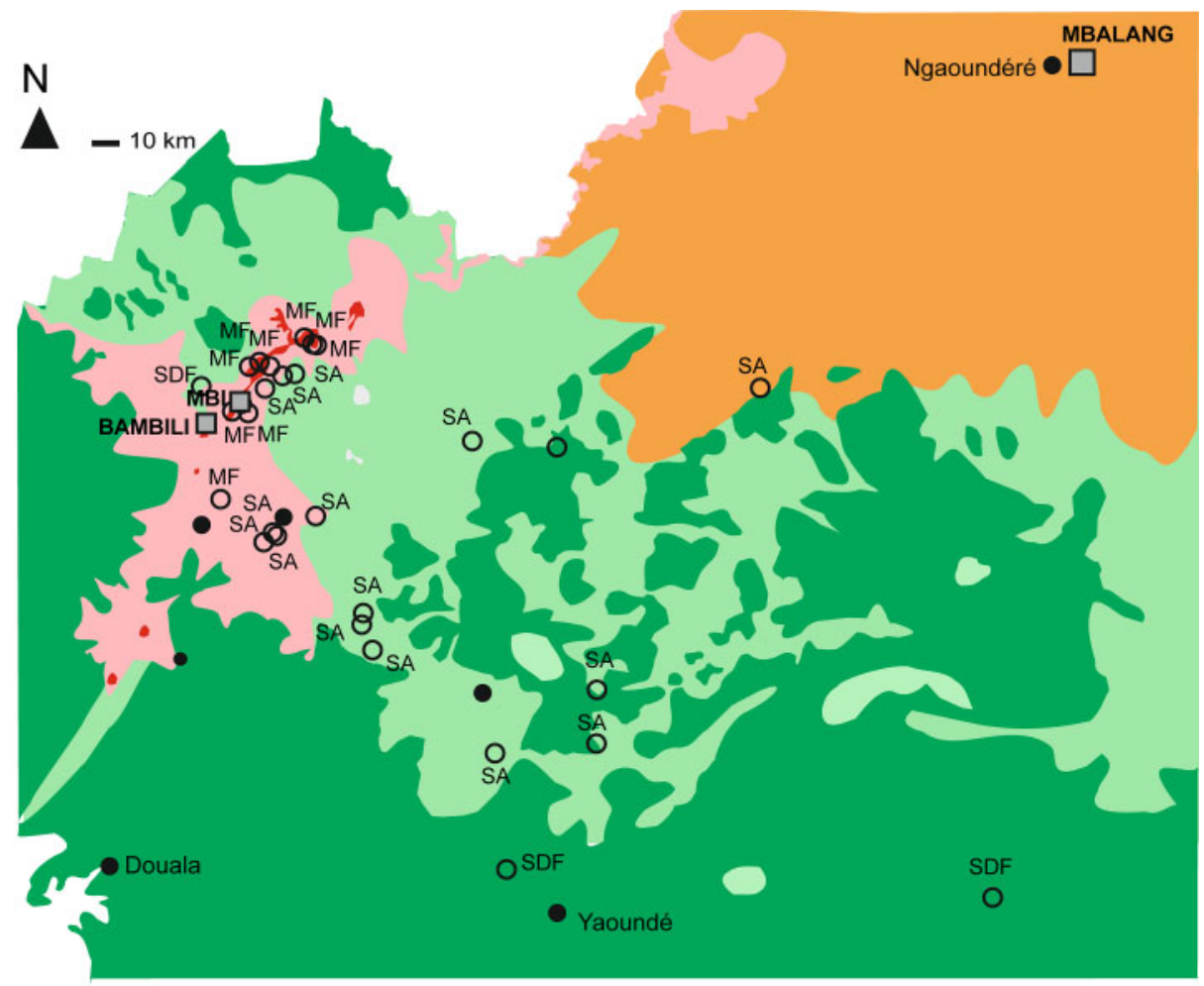

\section{Guineo-Congolian sector}

Rain and semi-deciduous forests

Secondary forests and grasslands

\section{Sudano-Guinean sector}

Wooded grasslands (Adamawa plateau)

\section{Montane and sub-montane sector}
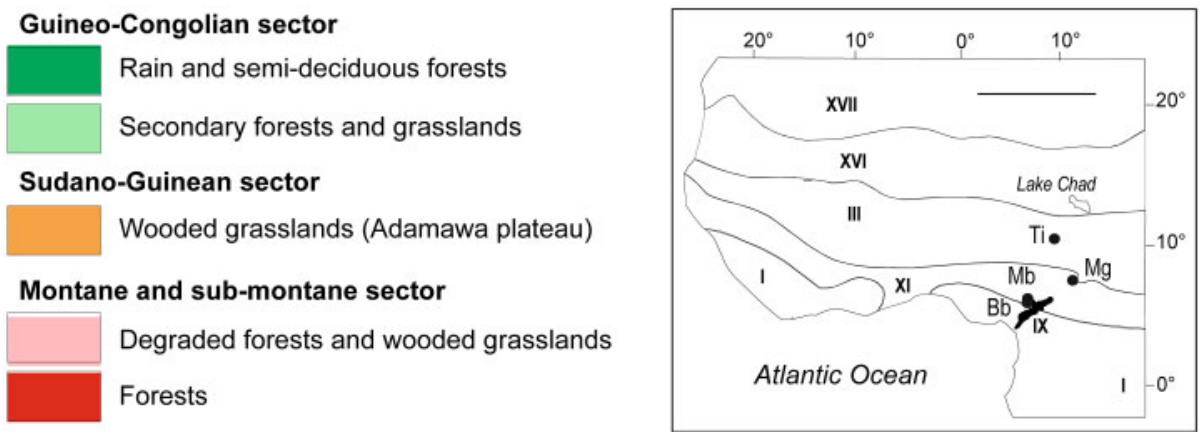

Fossil pollen sites

O Modern samples

Figure 1. Location of sites for the study of relative pollen productivities (surface soil samples and vegetation surveys) and fossil pollen records used for the application of the Landscape Reconstruction Algorithm. Simplified vegetation map of Cameroon (from Letouzey (1985) and White (1983), modified). Small map, lower right corner: I.

Guineo-Congolian centre of endemism; XI. Guineo-Congolian/Sudanian transition zone; III. Sudanian centre of endemism; XVI. Sahelian transition zone. XVII. Saharan transition zone. Abbreviations: modern samples: MF montane forest; SA savannah; SDF semi-deciduous forest; fossil pollen sites: Bb Bambili; Mb Mbi; Mg Mbalang; Ti Tilla.

Table S1). For further details on the methods used for collection of the pollen samples and vegetation surveys, pollen analysis, vegetation data handling, and on data access please see Supplementary Online Material, SOM-12.1. 


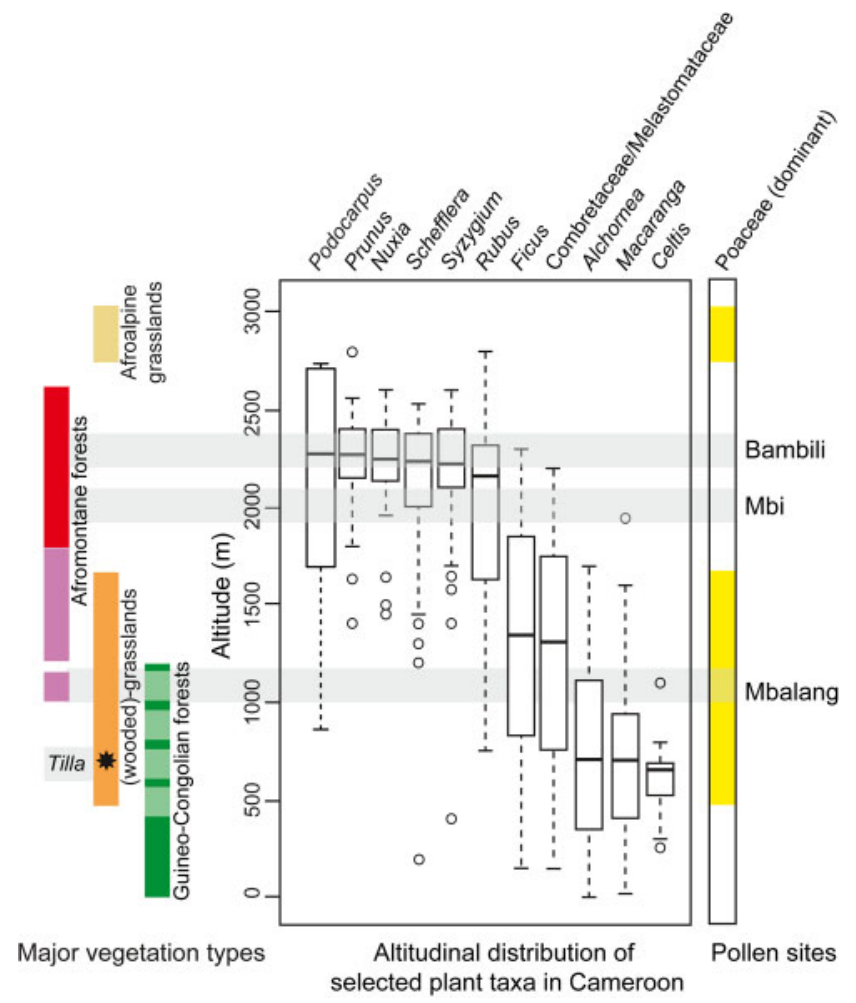

Figure 2. Altitudinal distribution of plant taxa discussed in the text (from Verlhac et al. 2018; modified). The altitudinal distribution of the main vegetation types (from Letouzey 1985) is shown on the left, while the altitudinal occurrence of Poaceae as a dominant taxon in wooded and open grasslands is indicated on the right. The colours refer to those in Figure 1 (except for Poaceae) and Figures 3, 5 and 6. The altitudinal location of pollen sites used for the LRA reconstructions is shown on the right, and the Nigerian site (Tilla) on the left. * indicates that the site Tilla belongs to another grassland system than the Cameroon sites (Figure 1).

\subsubsection{The Erv Model and Erv Analysis}

Detailed overviews of the underlying theory and assumptions of the ERV model and its developments can be found in Gaillard et al. (2008) and Bunting et al. (2013). Details on models and methods used for calculation of RPPs, and the computer programme for the ERV analysis are provided in SOM-12.1.4.

In this study, we used the three ERV sub-models developed by Parsons and Prentice (1981), Prentice and Parsons (1983), and Sugita (1994). The application of the ERV sub-models requires the following inputs:

- Pollen data: pollen \% of taxon $\mathrm{i}$ at site $\mathrm{k}$. In this study the maximum number of taxa analysed is 26 and $\mathrm{k}$ is a soil sample from a $1 \mathrm{~m}^{2}$ area, for 30 sites (SOM-12.1, Table S2)

- Radius of the sedimentary basin: distance in $\mathrm{m}$. In this study this is the radius of the area from which soil was collected, i.e. $0.5 \mathrm{~m}$.

- Reference taxon: the RPP of the reference taxon is set to 1, and the RPP of all other taxa included in the analysis are related to that reference taxon. In this study Poaceae is used as the reference taxon. 
- Vegetation data: Non-distance-weighted vegetation abundance of taxon $\mathrm{i}$ around site $\mathrm{k}$. In this study percentage cover is used, from 0.5 to $3000 \mathrm{~m}$ in $5 \mathrm{~m}$-concentric rings working out from the sampling location.

- $Z_{\max }$ : distance within which most pollen comes from. In this study estimated to be $200 \mathrm{~km}$ (see SOM-12.1.4).

The ERV model also requires that vegetation data is distance-weighted. We used three alternative models, 1/d (Prentice and Webb 1986), 'Prentice's model' for bogs (uses a Gaussian plume diffusion model (P-GPM) and assumes pollen deposition at one point; Prentice (1985)), and the Lagrangian Stochastic Model (LSM) (Kuparinen 2006; Kuparinen et al. 2007). P-GPM and LSM describe dispersion and deposition of pollen in different ways (e.g. Theuerkauf et al. 2013). For the application of these two models, additional inputs are needed:

- Fall speed of pollen (FSP) (m/s) of each taxon used in the analysis; FSP was calculated for the 26 taxa that were used in the ERV 'start run' (Table S2; see SOM-12.1 for details on the ERV analysis strategy and methods to calculate fall speed of pollen).

- Wind speed $(\mathrm{m} / \mathrm{s})$, in this study $3 \mathrm{~m} / \mathrm{s}$; ; this wind speed is widely used in the RPP studies performed in the Northern Hemisphere; it is also close to the modern average 10-m wind speed over land in Europe and China (e.g. Grassi et al. 2015), and the global average 10-m wind speed over land (3.28 m/s (class 1), Archer and Jacobson 2005).

The ERV analysis estimates the RPPs and their standard errors (SEs) using the maximum likelihood method (Stuart and Ord 1994) and quantifies the best 'linear fit' between pollen percentages and distance-weighted plant abundances using the likelihood function score (LFS, Prentice and Parsons 1983) or log likelihood (log L; e.g. Li et al 2017) over distance (see SOM12.1 for details). Beyond the distance at which the best linear fit is achieved, the curve of LFSs and $\log$ Ls reach an asymptote, i.e. do not decrease, respectively increase with distance.

The main outputs of one ERV analysis using the three ERV sub-models and the three distance-weighting models, i.e. nine runs of ERV analysis in total are:

- Vegetation dispersion with distance (a measure of vegetation stationarity, see SOM-12.1.3) (Figure 3A),

- Mean plant composition with distance for each taxon used in the analysis (Figure 3A),

- Adjusted pollen proportions (submodels 1 and 2) or relative pollen loading (submodel 3) and vegetation proportions $(1,2)$ or absolute vegetation abundance $(3)$ as calculated by the maximum likelihood method; empirical modern pollen data are expressed in percentages, which implies a non-linear pollen-vegetation relationship that would not have any algebraic solution for the RPPs and the 'background pollen' in the ERV model equation. The pollenvegetation relationship needs therefore to be linearized (Figure 4) (see SOM-12.1.4 for details),

- LFS and $\log$ L with distance (Figure 3A),

- RSAP (sensu Sugita 1994) calculated with the moving-window regression approach developed by S. Sugita (in Gaillard et al. 2008); RSAP is $Z_{R S A P}$ in the ERV model equation, i.e. the distance beyond which the 'background pollen' (second term in the ERV model's equation, $\omega_{i}$ ) is constant between sites within a region characterized by stationary vegetation; it is also the distance at which the linearity of the pollen-vegetation relationship is best and does not improve with distance (see SOM-12.1.4 for details); stationary vegetation implies that any area (e.g. $10 \mathrm{~km} \times 10 \mathrm{~km}$ ) has the same species composition as any other such area within the study region,

- RPP and their standard errors (SEs) with distance for each taxon used in the analysis (Figure 3B).

Details on the ERV analysis strategy are provided in SOM-12.1.4. The first ERV analysis run used the 26 taxa with both pollen and vegetation data in $\geq 5$ sites (Table S2). Based on plots 

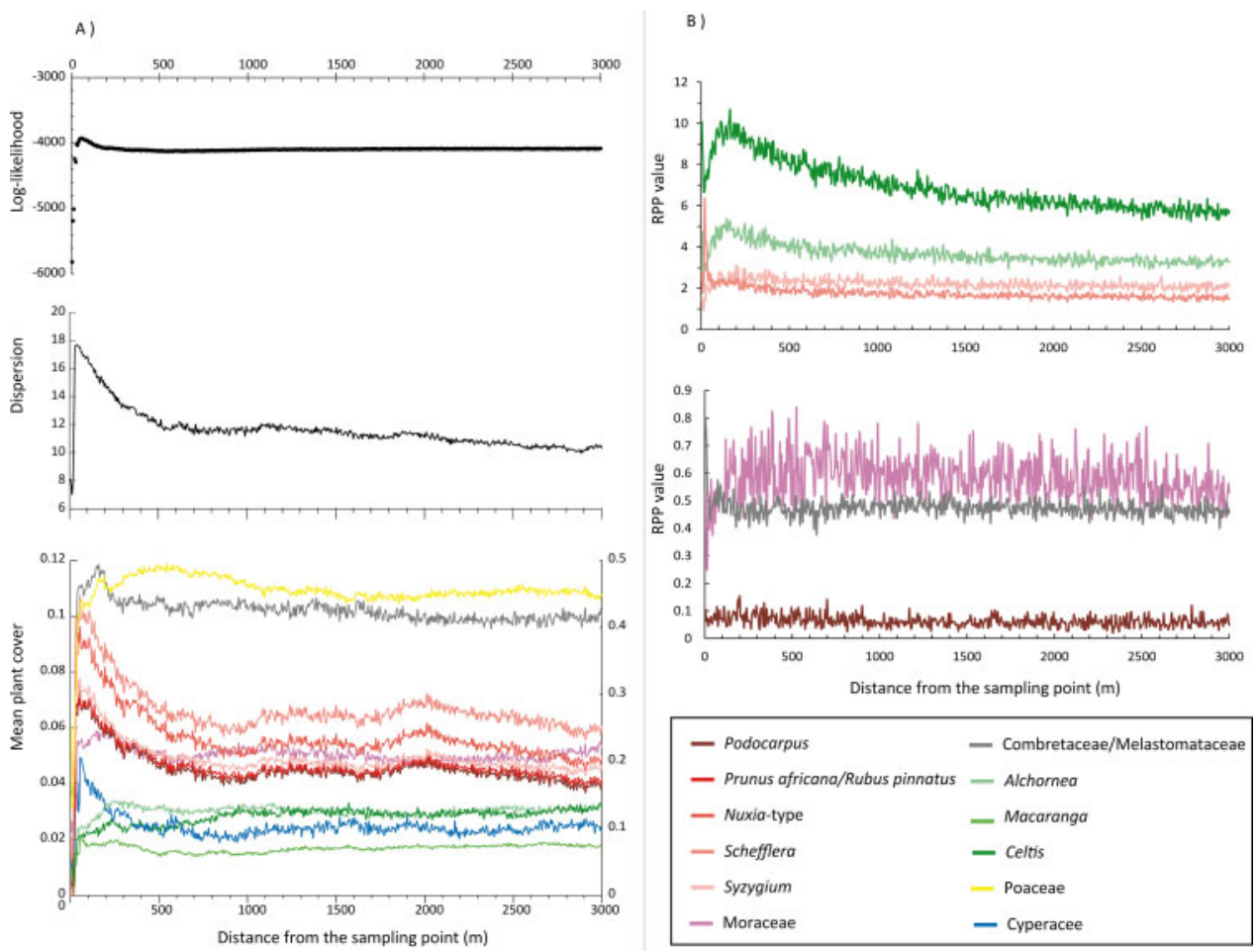

\begin{tabular}{|ll|}
\hline - Podocarpus & - Combretaceae/Melastomataceae \\
- Prunus africana/Rubus pinnatus & - Alchornea \\
- Nuxia-type & - Macaranga \\
- Schefflera & - Celtis \\
- Syzygium & - Poaceae \\
- Moraceae & - Cyperacee \\
\hline
\end{tabular}

Figure 3. Examples of results from the ERV analysis of pollen and vegetation data from 30 sites in Cameroon (see Figure 1 for site distribution). This analysis used 12 taxa, ERV submodel 2 and the Prentice's Gaussian Plume Model for distance weighting of vegetation (see Methods and SOM-12.1.4 for details). (A) Log likelihood, vegetation dispersion, and mean taxa composition (in proportion) over distance from the pollen sample points; note that the scale for Poaceae is on the right of the diagram. (B) Relative Pollen Productivities (RPPs) with distance from the pollen sample points for seven taxa. The colours relate to those in Figures 1, 2, 5 and 6; the five shades of red (dark brownish red to light pink) relate to the red colour in Figures 1 and 2 and to the five shades of red in Figures 5 and 6 ; the three shades of green relate to Figures 1 and 2 two shades of green together and to the three shade of green in Figures 5 and 6.

of adjusted pollen percentages and vegetation proportions (Figure 4), the taxa with the best linear relationships were selected for the next runs of ERV analysis. In this paper, we present the results of the ERV analysis that produced the curve of $\log \mathrm{L}$ closest to the theoretically correct curve (increases and reaches an asymptote at a certain distance; SOM-12.1.4), which was obtained with 12 taxa, ERV sub-model 2, and P-GPM for distance weighting of vegetation (Figure 3A; Table 1A).

\subsubsection{Landscape Reconstruction Algorithm (LRA)}

Details on the LRA and its assumptions are found in SOM-12.2.3. LRA comprises two models, REVEALS (REgional VEgetation Abundance from Large Sites) (Sugita 2007a) and LOVE (LOcal VEgetation Estimates) (Sugita 2007b). Both models reduce biases due to inter-taxonomic differences in pollen productivity and basin size. REVEALS estimates the mean regional vegetation composition of plant taxa in proportion (dimensionless) for a large region (minimum $100 \mathrm{~km} \times 100 \mathrm{~km}$; Hellman et al. 2008) using pollen records from large lakes. REVEALS assumes that no plants are growing on the deposition basin (Sugita 2007a). Therefore, model 


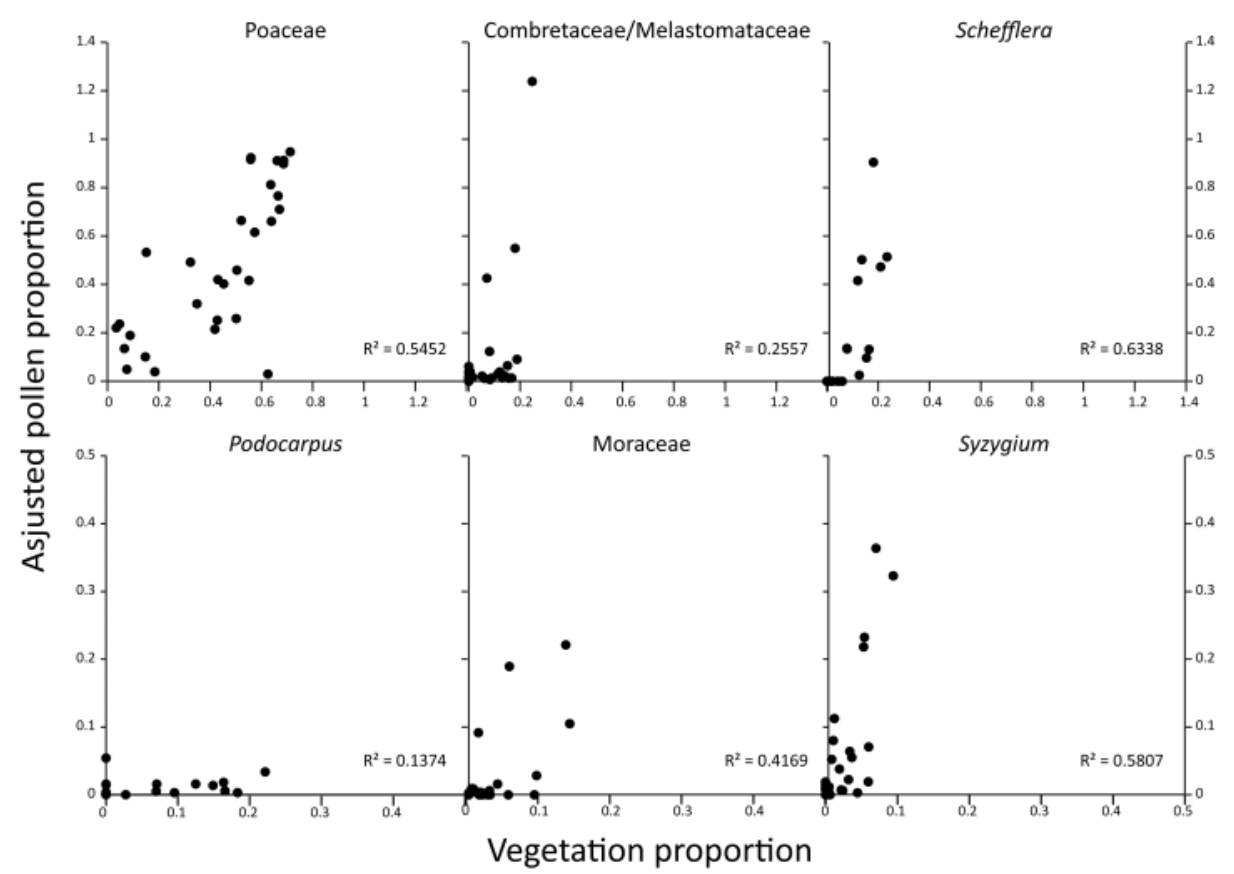

Figure 4. Examples of ERV-corrected pollen-vegetation relationships for six taxa from the ERV analysis using the full pollen-vegetation dataset (30 sites), 12 taxa, ERV submodel 2 and the Prentice's Gaussian Plume Model for distance weighting of vegetation (see Methods and SOM-12.1 for details). The coefficient of determination $\left(\mathrm{R}^{2}\right)$ is provided as a measure of linearity, the higher the value the more linear the relationship.

estimates from pollen assemblages in large bogs will be biased by pollen coming from the surface of the bog. LOVE estimates 'background pollen' using REVEALS estimates of regional vegetation, and subtracts 'background pollen' to derive local vegetation cover within the RSAP (see ERV model above and SOM-12.1). The RSAP represents the smallest spatial scale of the LOVE reconstruction. Both REVEALS and LOVE provide estimates of plant abundance/cover with their SEs. Note that the plant abundance estimated by LOVE is distance weighted.

The application of the LRA requires a minimum of two pollen records from the same vegetation/landscape type, one from a large lake for a REVEALS-based reconstruction of the regional plant cover, and one from a small lake for a LOVE reconstruction of the local plant cover. However, calculation of the RSAP of small sites requires pollen records from several sites (see SOM-12.2.3 for further explanations). Due to the small number of pollen records appropriate for a LRA in the study region, we made the following assumptions:

(1) Pollen of Cyperaceae are primarily of local origin, growing on the swamp (Mbi) or at lake shores (Bambili, Tilla, Mbalang), and Cyperaceae are the dominant plants in these biotopes,

(2) The RSAP of the small sites is $2 \mathrm{~km}$ (SOM-12.2.3),

(3) The pollen record (Cyperaceae excluded) from Mbi and Tilla represent the mean regional vegetation cover around Bambili and Mbalang, respectively.

Possible departures from these assumptions are described in SOM-12.2.3. A local origin of most pollen from Cyperaceae is supported by the analysis of $>1000$ modern pollen samples from Africa, Madagascar and Arabia (Gajewski et al. 2002) suggesting that Cyperaceae pollen is related primarily to humid regions and habitats in Africa. 
Table 1. Habitus, pollination, Fall Speed of Pollen (FSP) and Relative Pollen Productivities (RRP) with their standard errors (SE) for 12 major taxa in: (A) Cameroon (this study), (B) from other studies in South Africa (Hill et al., this volume); Namibia (Tabares et al. 2021); Bolivia (Whitney et al. 2018); Brazil (Piraquive Bermúdez et al. 2019); and (C) from other studies in Subtropical China: left (Fang et al. 2020), centre (Jiang et al. 2020), right (Chen et al. 2019); Tropical China (Wan et al. 2020). ^ FSP from Jiang et al. (2020). Reference taxon (Poaceae=1): * indicates that Poaceae is the reference taxon used in the analysis. ** indicates that other taxa were used as reference and RPP values were converted to Poaceae $=1$. Abbreviations: $\mathrm{H}$ herb, S shrub, T tree; Pollinat Pollination; A anemophilous, E entomophilous; (A) and (E) indicate that the one type of pollination is less common than the other.

(A) Cameroon (this study)

\begin{tabular}{lccccc}
\hline Taxa & Habitus & Pollinat. & FSP $(\mathrm{m} / \mathrm{s})$ & RPP & SE \\
\hline Alchornea & $\mathrm{S} / \mathrm{T}$ & $\mathrm{E} / \mathrm{A}$ & 0.012 & 4.00 & 0.188 \\
Celtis & $\mathrm{T}$ & $\mathrm{E} / \mathrm{A}$ & 0.010 & 7.00 & 0.270 \\
Combretaceae/Melastomataceae & $\mathrm{T} / \mathrm{H}$ & $\mathrm{E}$ & 0.012 & 0.50 & 0.039 \\
Cyperaceae & $\mathrm{H}$ & $\mathrm{A} /(\mathrm{E})$ & 0.022 & 0.23 & 0.045 \\
Macaranga & $\mathrm{T}$ & $\mathrm{E} / \mathrm{A})$ & 0.013 & 1.70 & 0.054 \\
Moraceae & $\mathrm{T}$ & $\mathrm{A} / \mathrm{E}$ & 0.006 & 0.60 & 0.070 \\
Nuxia type & $\mathrm{T}$ & $\mathrm{E}$ & 0.003 & 1.40 & 0.397 \\
Poaceae & $\mathrm{H}$ & $\mathrm{A}$ & 0.035 & $1.00^{*}$ & 0.000 \\
Podocarpus & $\mathrm{T}$ & $\mathrm{A}$ & 0.017 & 0.06 & 0.018 \\
Prunus africana/Rubus pinnatus & $\mathrm{T}$ & $\mathrm{E}$ & 0.013 & 0.40 & 0.037 \\
(Rosaceae) & & & $(0.021)^{\wedge}$ & & \\
Schefflera & $\mathrm{T}$ & $\mathrm{E}$ & 0.009 & 1.80 & 0.164 \\
Syzygium & $\mathrm{T}$ & $\mathrm{E}$ & 0.003 & 2.20 & 0.107 \\
\hline
\end{tabular}

\begin{tabular}{|c|c|c|c|c|c|c|c|c|}
\hline \multirow{2}{*}{$\frac{\text { (B) Other studies: }}{\text { Taxa }}$} & \multirow{2}{*}{$\frac{\text { S Africa }}{\text { RPP }}$} & \multicolumn{2}{|c|}{ Namibia } & \multirow{2}{*}{$\frac{\text { Bolivia }}{\text { RPP }}$} & \multicolumn{4}{|c|}{ Brazil } \\
\hline & & RPP & $\mathrm{SE}$ & & RPP & $\mathrm{SE}$ & RPP & SE \\
\hline \multicolumn{9}{|l|}{ Alchornea } \\
\hline \multicolumn{9}{|l|}{ Celtis } \\
\hline Comb./Mel. & & 0.217 & 0.014 & & & & & \\
\hline Cyperaceae & & & & & 0.48 & 0.11 & 0.63 & 0.33 \\
\hline \multicolumn{9}{|l|}{ Macaranga } \\
\hline Moraceae & & & & 0,25 & & & & \\
\hline \multicolumn{9}{|l|}{ Nuxia type } \\
\hline Poaceae & $1.00 *$ & $1.00 *$ & 0.00 & $1.00 * *$ & $1.00 * *$ & 0.00 & $1.00 * *$ & 0.00 \\
\hline Podocarpus & 6.50 & & & & & & & \\
\hline \multirow{2}{*}{\multicolumn{9}{|c|}{$\begin{array}{l}\text { P. africana/R. pinnatus } \\
\text { (Rosaceae) }\end{array}$}} \\
\hline & & & & & & & & \\
\hline \multicolumn{9}{|l|}{ Schefflera } \\
\hline Syzygium & & & & & & & & \\
\hline
\end{tabular}


Table 1. Continued

\begin{tabular}{|c|c|c|c|c|c|c|c|c|}
\hline \multirow{2}{*}{$\frac{\text { (C) Other studies: }}{\text { Taxa }}$} & \multicolumn{6}{|c|}{ Subtropical China } & \multicolumn{2}{|c|}{ Tropical China } \\
\hline & RPP & SE & RPP & SE & RPP & $\mathrm{SE}$ & RPP & SE \\
\hline $\begin{array}{l}\text { Alchornea } \\
\text { Celtis } \\
\text { Comb./Mel. } \\
\text { Cyperaceae }\end{array}$ & & & & & & & & \\
\hline Macaranga & & & & & & & 2.21 & 0.08 \\
\hline $\begin{array}{l}\text { Moraceae } \\
\text { Nuxia type }\end{array}$ & & & & & 0.50 & 0.35 & 6.52 & 0.08 \\
\hline $\begin{array}{l}\text { Poaceae } \\
\text { Podocarpus }\end{array}$ & $1.00 *$ & 0.00 & $1.00 * *$ & 0.00 & $1.00 * *$ & 0.00 & $1.00 *$ & 0.00 \\
\hline $\begin{array}{l}\text { P. africana/R. pinnatus } \\
\text { (Rosaceae) } \\
\text { Schefflera } \\
\text { Syzygium }\end{array}$ & 0.41 & 0.28 & 0.84 & 0.045 & 1.00 & 0.45 & & \\
\hline
\end{tabular}

Relying on the three assumptions above, we used the pollen records from Mbi and Tilla (large lake sites) for REVEALS reconstructions of the regional plant abundance, and from Bambili and Mbalang (small lake sites) for the LOVE reconstructions of the local plant abundance around each lake. We excluded Cyperaceae from the pollen records and used the 11 taxa for which we have RPP estimates (Table 1A). In addition, we tested alternative RPP values for Podocarpus, i.e. the mean RPPs of Pinus (6.38) and Picea (2.62) in Europe, to evaluate their effect on the reconstructions and discuss them in the light of the existing knowledge on the dispersal and deposition of Podocarpus pollen. Only one additional RPP value is available for Podocarpus to date, i.e. 6.54 (related to Poaceae) from a study in South Africa (Duthie 2015; Hill et al., this volume) (Table 1B). Pinus, Picea and Podocarpus all belong to coniferous plants for which large pollen productivity is common. Note also that Hill et al.'s value is very close to Pinus mean RPP in Europe. The REVEALS and LOVE reconstructions were performed for continuous 500-year time windows over the last 12 ka years, except for Mbalang (last 6 ka years). $Z_{\max }$ was set to $200 \mathrm{~km}$ and wind speed to $3 \mathrm{~m} / \mathrm{s}$ (see 12.1.4, above, and SOM-12.1.4). We used the computer programme LRA.REVEALS.v6.2.4.exe and LRA.LOVE.v6.2.3.exe (Sugita, unpublished) to calculate the REVEALS estimates of regional plant cover at Mbi and Tilla and LOVE estimates of local plant cover within $2 \mathrm{~km}$-radius areas around Bambili and Mbalang. See SOM-12.2.3 for details on access to the computer programmes.

\subsection{RESULTS}

\subsubsection{ERV analysis and RPP estimates}

Vegetation dispersion and mean plant cover over distance from the pollen sample points (Figure 3A) based on the collected vegetation dataset (SOM-12.1.3) indicate that the ERV model's assumption of stationary vegetation is violated in the study region. Both vegetation dispersion and mean plant cover increase with distance until maximum values at $c$. $50-100 \mathrm{~m}$ and then decrease until c. $600 \mathrm{~m}$ instead of reaching an asymptote. The values of mean plant cover for Alchornea, Macaranga, Celtis, Moraceae and Poaceae indicate that these taxa have a more stable 
composition already from $c .200 \mathrm{~m}$. The log likelihood curve shows a similar pattern as vegetation dispersion, although with a much less prominent 'overshoot' of the curve at $50 \mathrm{~m}$. From $600 \mathrm{~m}$, the values of mean plant cover remain relatively constant for all plant taxa. This distance also corresponds to the RSAP ( $585 \mathrm{~m}$ ) as calculated from the $\log \mathrm{L}$ curve (Figure $3 \mathrm{~A}$ ) with the moving-window regression method. An attempt to analyse forest and savannah sites separately to decrease vegetation dispersion did not improve the results; instead, the log L curves diverged from the theoretically correct curve even more (results not shown).

Most curves of RPPs plotted against distance from the pollen sample point deviate from the expected behaviour (increase to reach an asymptote at a certain distance), but the RPP values are relatively constant from $c .1500 \mathrm{~m}$ for all taxa except Celtis. The RPPs of Podocarpus exhibit more or less constant values over $3 \mathrm{~km}$. The RPPs of Combretaceae/Melastomataceae and Schefflera reach maximum values at very short distances, decrease abruptly, and maintain relatively constant values from a few metres. The RPPs of Alchornea and Celtis increase to maximum values at c. $200 \mathrm{~m}$ and then decrease gradually until $1500 \mathrm{~m}$ and $3000 \mathrm{~m}$, respectively. The RPPs of Moraceae and Syzygium increase until $200 \mathrm{~m}$ where they reach an asymptote, although the values of Moraceae are very unstable. Because RPPs still decrease after the calculated RSAP distance $(585 \mathrm{~m})$, we selected the final RPP values at the distance for which they stabilize for all taxa, i.e. $1500 \mathrm{~m}$ (Table1A).

Figure 4 presents examples of ERV model-corrected pollen-vegetation relationships for six of the 12 taxa. Schefflera, Poaceae and Syzygium exhibit the most linear relationships with coefficients of determination $\left(\mathrm{R}^{2}\right)$ of $0.63,0.54$ and 0.58 , respectively. Moraceae and Combretaceae/Melastomataceae have weaker linear relationships with $\mathrm{R}^{2}$ values of 0.42 and 0.26 , respectively. $\mathrm{A}^{2}$ value of 0.14 indicates a very weak linearity for Podocarpus, Combretaceae/Melastomataceae, Schefflera, and Syzygium are strongly overrepresented, Poaceae is slightly overrepresented, and Podocarpus strongly underrepresented by pollen. The pollen-vegetation relationship of Moraceae clearly indicates either overrepresentation or underrepresentation by pollen depending on the site.

\subsubsection{Landscape Reconstruction Algorithm (LRA): Regional and local plant cover}

The REVEALS reconstructions represent regional plant abundance in an area of $c .100 \mathrm{~km} \times$ $100 \mathrm{~km}$ around Mbi and Tilla, and the LOVE reconstructions the local plant abundance in an area of minimum $2 \mathrm{~km}$ radius around Bambili and Mbalang (see Methods and SOM-12.2.4). The REVEALS and LOVE estimates with their SEs for the 11 taxa are provided for Mbi and Bambili in Figures S2-S5) and highlight the effect of the RPPs' SEs on the reconstructions. Podocarpus, Nuxia-type, Moraceae, and Prunus africana/Rubus pinnatus have the largest SEs in relation to their RPP value (Table 1A). These taxa also exhibit the largest SEs of LRA reconstructions. When RPP 0.06 is used for Podocarpus, SEs are very large for Podocarpus and relatively large for Nuxia-type (for both REVEALS and LOVE plant cover) (Figure S2). SEs are also quite large for Moraceae and Prunus africana/Rubus pinnatus (for LOVE plant cover) in the Early Holocene (Figures S2 and S3). All other taxa exhibit small SEs over most of the Holocene. There are generally few values not different from zero (i.e. SD $\geq$ REVEALS/LOVE estimate) and they occur mainly for very low values of plant cover, except for Podocarpus (RPP 0.06) that has also very large SEs for high LOVE plant cover over most of the Holocene (Figure S2).

\subsubsection{Mountain woodlands: Mbi and Bambili (Figure 5; Figures S2-S5)}

The pollen sum of the 11 taxa used in the LRA reconstructions represent $61-81 \%$ (mean $69.4 \%$ ) (Mbi) and 59-76\% (mean 65.5\%) (Bambili) of the total pollen sum of terrestrial plant taxa (SOM-12.2.1, Table S3A). The REVEALS and LOVE reconstructions are strongly influenced by the RPP used for Podocarpus. The low RPP (0.06) results in a very strong dominance of Podocarpus 9.5-0.5 ka BP in the regional vegetation (Mbi) and 10.5-2 ka BP locally around 

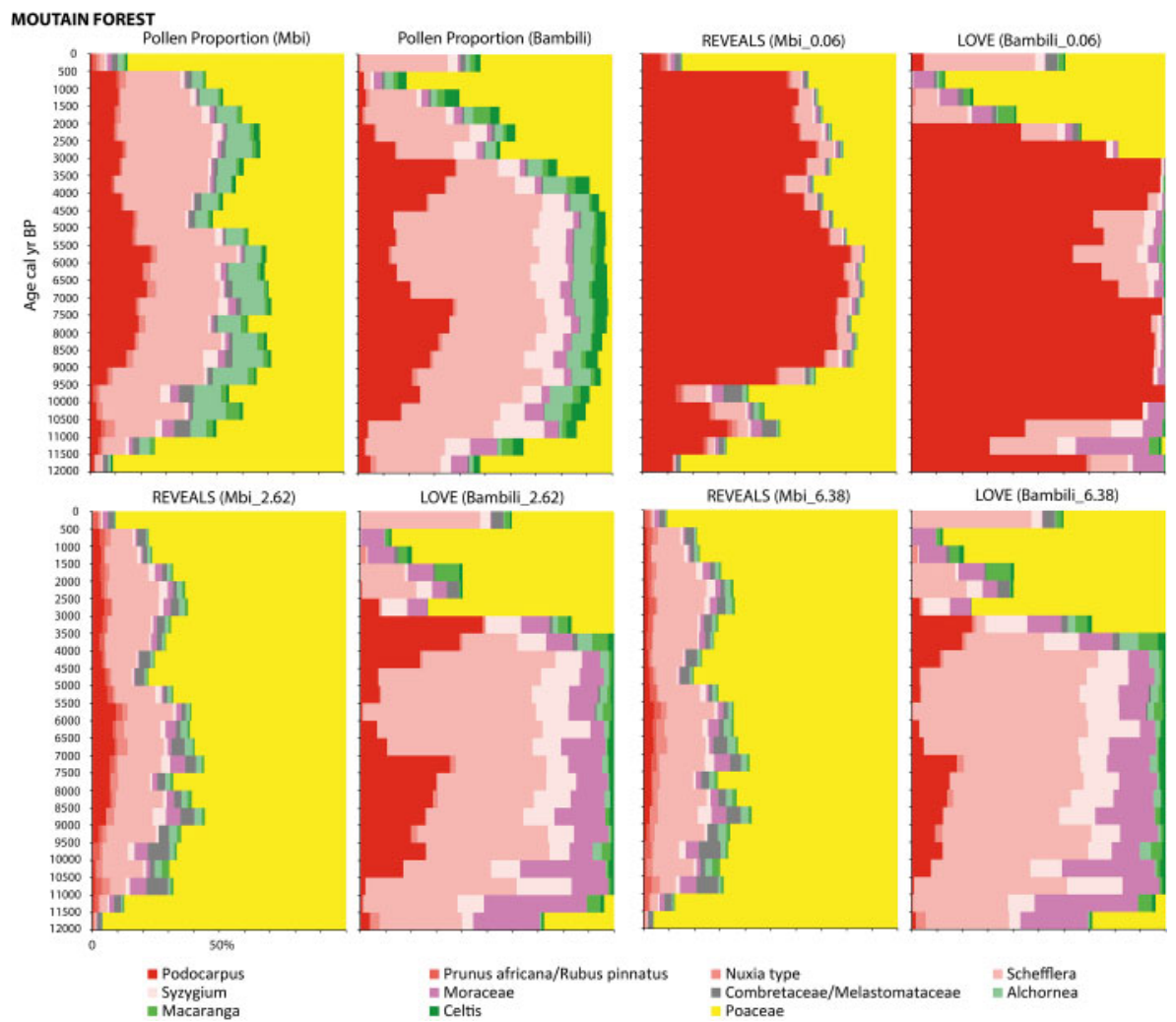

LOVE (Bambili_6.38)

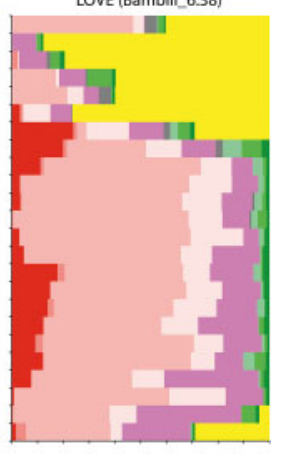

Poaceae

Figure 5. REVEALS-based regional and LOVE-based local plant cover using the pollen records from Mbi and Bambili, respectively, and three alternative RPPs for Podocarpus (0.06, 2.62, and 6.38). Plant cover in percentage of an area of $100 \mathrm{~km} \times 100 \mathrm{~km}$ for Mbi, and of minimum $2 \mathrm{~km}$ radius for Bambili. Upper panel: pollen percentages for Mbi and Bambili, REVEALS (Mbi)- and LOVE (Bambili)-based plant cover using 0.06 for Podocarpus; Lower panel:

REVEALS (Mbi)- and LOVE (Bambili)-based plant cover using RPP 2.62 (left) and 6.38 (right) for Podocarpus. The colours relate to those in Figures 1,2 and 3; the five shades of red correspond to carmine red and three shades of green to the two shades of green together in Figures 1 and 2.

Bambili. The other nine tree taxa have a reduced abundance compared to their pollen $\%$, except Moraceae. Regional woodland cover (Mbi) is larger than total tree pollen \%, and local woodland cover at Bambili is 100\% 12-3 ka BP while percentages of total tree pollen increase from $c .50 \%$ (12 ka BP) to $97-98 \%(8-4.5 \mathrm{ka} \mathrm{BP})$ to decrease back to $c .55 \%$ at $3 \mathrm{ka} \mathrm{BP}$.

When higher RPPs (2.62 and 6.38) are used for Podocarpus, regional openland (Poaceae) around Mbi represents $>50 \%$ of the total vegetation cover over the entire Holocene, while pollen \% exceed 50\% only 12-11 ka BP, 5-4.5 ka BP, and $1 \mathrm{ka} \mathrm{BP}$ to present. In contrast, local vegetation cover at Bambili is 100\% wooded 11-3.5 ka BP, and the decrease of woodland from $3 \mathrm{ka} \mathrm{BP}$ is much larger and more abrupt than the decrease in total tree pollen \%. Woodland cover drops from $100 \%$ to $29 \%$ (RPP 2.62) or $22 \%$ (RPP 6.38) between 3.5 and $3 \mathrm{ka} \mathrm{BP,} \mathrm{whereas}$ pollen \% decrease from $98 \%$ to $55 \%$ between 4.5 and 3 ka BP. While Podocarpus maintains pollen $\%>10 \%$ at Bambili $7-4.5 \mathrm{ka} \mathrm{BP}$, its reconstructed local cover around the site is < $10 \%$ and not different from zero $6-5.5 \mathrm{ka} \mathrm{BP}$ (Figure S2). The major effect of using RPP 2.62 rather than 6.38 on the reconstruction of regional vegetation is a larger cover (c. double) of Podocarpus throughout the Holocene at the expense of Poaceae, while the cover of other trees does not change significantly. The largest differences in composition of tree taxa between pollen $\%$ 
and regional plant cover (Mbi) is mainly a larger cover of Combretaceae/Melastomataceae in relation to Alchornea, Macaranga, and Celtis. In terms of the local tree composition around Bambili, the major difference between pollen percentage and plant cover is a larger cover of Schefflera at the expense of Podocarpus 10.5-3.5 ka BP, and a larger cover of Moraceae and Macaranga at the expense of Alchornea and Celtis (except for the last 50 years). In recent time, the cover of Combretaceae/Melastomataceae is larger than earlier and Schefflera dominates the tree cover.

\subsubsection{The Sudanian and Guineo-Congolian wooded grasslands: Tilla and Mbalang}

The pollen sum of the 11 taxa used in the LRA reconstructions represent $68.1-95.8 \%$ (mean $82.7 \%$ ) (Tilla) and 48.7-94\% (mean 72.2\%) (Mbalang) of the total pollen sum of terrestrial plant taxa (SOM-12.2.1, Table S1A) (Figure 6). The REVEALS reconstructions of regional plant cover around Tilla are characterized by a very large cover of openland (Poaceae) throughout the Holocene whatever RPP is used. Moreover, the cover of Poaceae is larger than their pollen \%.
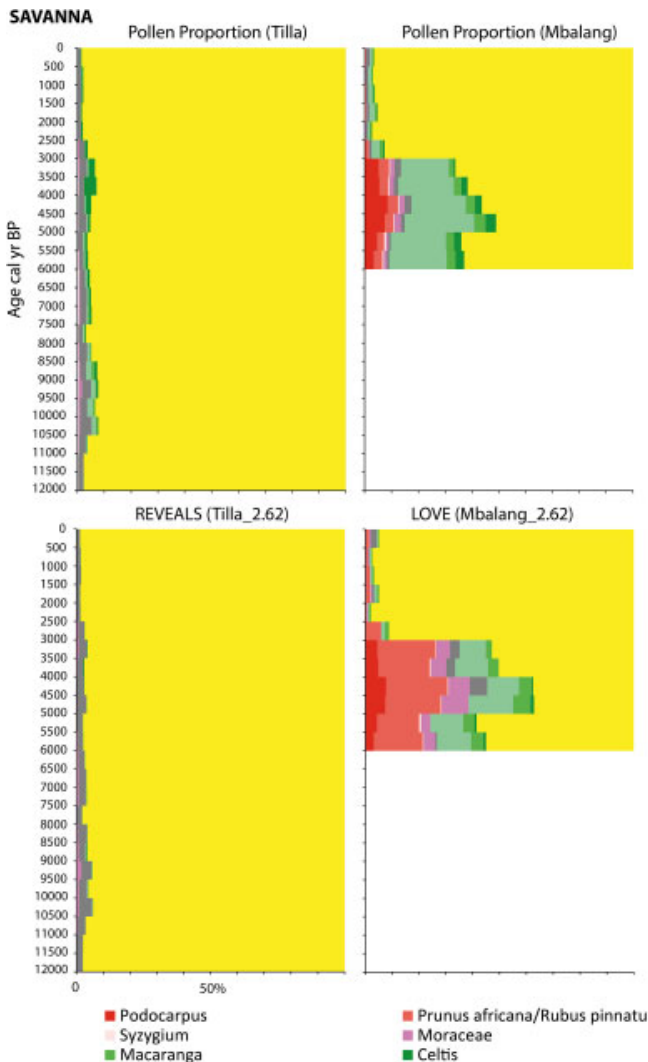

LOVE (Mbalang_2.62)
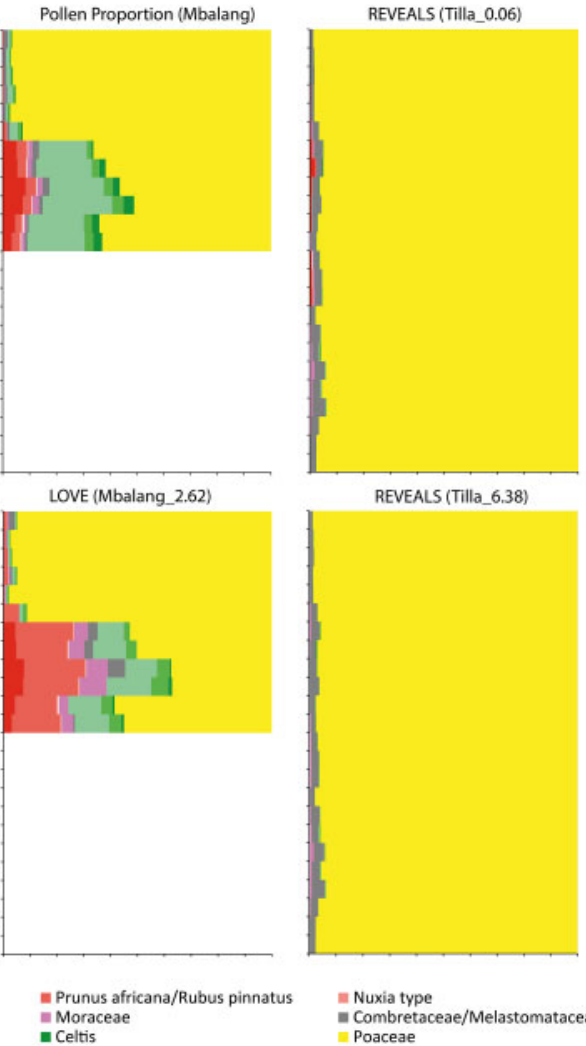

REVEALS (Tilla_6.38)
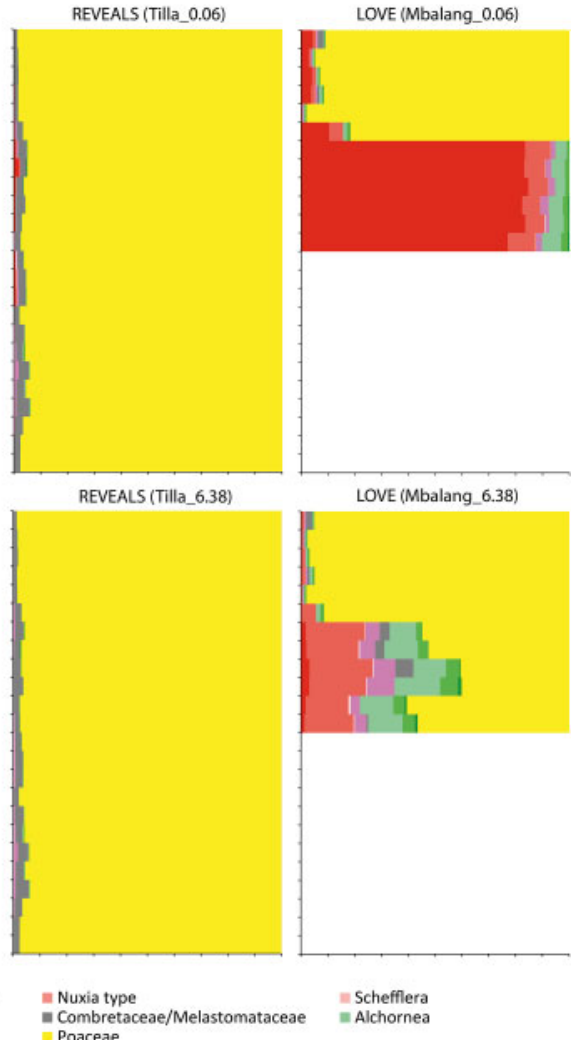

LOVE (Mbalang_6.38)

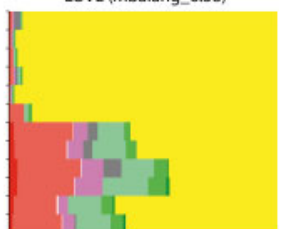

Schefflera

$=$ Alchornea

Figure 6. REVEALS-based regional and LOVE-based local plant cover using the pollen records from Tilla and Mbalang, respectively, and three alternative RPPs for Podocarpus $(0.06,2.62$, and 6.38). Plant cover in percentage of an area of $100 \mathrm{~km} \times 100 \mathrm{~km}$ for Tilla, and an area of minimum $2 \mathrm{~km}$ radius for Mbalang. Upper panel: pollen percentages for Tilla and Mbalang, REVEALS (Tilla)- and LOVE (Mbalang)-based plant cover using 0.06 for Podocarpus; Lower panel: REVEALS (Tilla)- and LOVE (Mbalang)-based plant cover using RPP 2.62 (left) and 6.38 (right) for Podocarpus. The colours relate to those in Figures 1 and 2; the five shades of red correspond to carmine red and three shades of green to the two shades of green together in Figures 1 and 2. 
There is no significant difference between the three reconstructions except a slightly larger cover of Podocarpus when RPP 0.06 is used. The total cover of trees is smaller than tree pollen \%, and Combretaceae/Melastomataceae are dominant over the other tree taxa, which is not the case in pollen $\%$.

The LOVE reconstructions for Mbalang exhibit a total cover of tree of $100 \%$ with RPP 0.06 for Podocarpus over the period 6-3 ka BP, and of 40-60\% with RPPs 2.62 and 6.38. With RPP 0.06 , Podocarpus is dominant, while all other trees have a cover smaller or much smaller than their pollen percentage, except Prunus africana/Rubus pinnatus and Moraceae that have a higher, respectively slightly higher cover than their pollen \%. With RPPs 2.62 and 6.38, Poaceae has a cover slightly smaller than its pollen \%, especially 6-3 ka BP. Prunus africana/Rubus pinnatus has a larger cover than its pollen \% over the entire period 6-0 ka BP, as well as Moraceae and Macaranga 6-3 ka BP, and Combretaceae/ Melastomataceae 4.5-3 ka BP. Podocarpus, Combretaceae/ Melastomataceae, Celtis and Alchornea have a smaller cover than their pollen \%. LOVE plant cover and pollen of Syzygium and Schefflera are similar in proportions. Podocarpus has a larger cover in the reconstruction with RPP 2.62 than in the one with RPP 6.38. The decrease in total trees at $3 \mathrm{ka} \mathrm{BP}$ is sharp in both cover and pollen \%, but the decrease in cover (48 to $9 \%$ ) is larger than in pollen $\%$ (30 to $7 \%$ ).

\subsection{DISCUSSION}

\subsubsection{Relative Pollen Productivity (RPP)}

\subsubsection{Effects of violation of model assumptions and other factors}

The effects on RPPs of deviations from the ERV model assumptions and other factors have been discussed earlier in syntheses of RPP values in Europe (Broström et al. 2008; Mazier et al. 2012), temperate China (Li et al. 2017) and the Northern hemisphere (Wieczorek and Herzschuh 2020). The number of factors affecting RPPs and/or causing between-study variability in RPP values for a taxon are numerous. They span from between-study region differences in climate, land use, vegetation type/structure and plant species (including their pollination strategies), between-study variation in methods used to collect the pollen-vegetation dataset (including methods in field and laboratory, and data handling), to differences between models and/or model implementation (including dissimilarities in parameter setting, parameter values, and calculation procedures). Because of the relatively low number of RPP values (response variables) compared to the number of factors (explanatory variables), statistical quantification of the effect of these factors on RPP estimates has never been attempted so far. In this pilot study, the major factors that need to be considered with care are the violation of the ERV model's assumptions in terms of stationarity of the vegetation in the study area, random distribution of sites, mode of dispersal and deposition of pollen, and taphonomy and preservation of pollen in soil samples.

Vegetation dispersion and mean plant composition over distance (Figure 3A) indicate that vegetation is not stationary in the study region, and site distribution did not follow a true random scheme, but a stratified random one. Both factors may explain the shape of the log L curves obtained from the ERV runs (example in Figure 3A) (e.g. Broström et al. 2005; Li et al. 2017). Moreover, the difference in vegetation data collection within and beyond $100 \mathrm{~m}$ (also seen in the difference in mean plant composition within and beyond $100 \mathrm{~m}$, Figure $3 \mathrm{~A}$ ) may also cause the 'overshoot' of $\log \mathrm{L}$ values at short distances $(<100 \mathrm{~m})$ before the curve decreases and/or plans out. The shape of the log L curve implies that the definition of the RSAP is uncertain. Based on the empirical and simulation study of Broström et al. (2005) on the effect of non-random site distribution on likelihood function scores and the identification of the RSAP, we assume that the large RSAP, i.e. the distance at which all curves of RPP with distance stabilize $(1500 \mathrm{~m})$, is most realistic. 
Eight of the twelve plant taxa involved in the analysis are entomophilous, of which three have been described as partly anemophilous (Table 1A). The assumption of the ERV model that all pollen is transported by wind is therefore violated. However, these taxa are common in lake sediments and peat deposits of tropical Africa, which suggests that part of the pollen produced is transported by wind. Therefore, an estimate of the relationship between vegetation and pollen transported to palaeoecological archives such as lakes and bogs remains useful. Nevertheless, such estimate will not be comparable with true pollen productivity in the plant stamina, but can be used as a measure of the proportion of pollen transported and deposited in soils, moss pollsters, lakes and bogs. The use of soil samples instead of moss pollsters in regions where mosses are uncommon and/or poor in pollen (e.g. Wan et al. 2020) may also imply biases of the pollen assemblages compared to mosses/lake sediment/peat. Gajewski et al. (2002) analysed a database of all surface pollen data available in Africa and concluded that percentages of the three most abundant pollen taxa did not show any bias among sampling methods. However many studies have indicated biases of pollen assemblages in soil samples compared to, e.g. pollen traps due to poor preservation conditions (e.g. Zhang et al. 2015). We therefore assume that the most common pollen types in soils are those that are well preserved due to their species/taxon-specific wall structure, and that their amount corresponds to the pollen transported and deposited in the soil. To our knowledge, little is known on the number of years of pollen deposition in soil samples (e.g. Havinga 1984). Thus, we assume that they represent some years of pollen deposition. One of the basic assumptions of pollen analysis as a tool to reconstruct past vegetation change is that pollen productivity is a constant, although pollen-trap studies have shown that inter-annual variation occurs in the absence of changes in plant cover (e.g. Abraham et al. 2021; Gosling et al. 2005; Haselhorst et al. 2013; Julier et al. 2019). These known variations are considered as 'noise' in terms of the pollen productivity measure needed to interpret sedimentary pollen records (e.g. Fang et al. 2020). Individual pollen assemblages from lake sediments or peat used? to be from multiple years-samples, and each quantitative reconstruction of plant cover using the LRA (REVEALS and LOVE) seldom represents less than 100 years, and generally covers 100 to 500 years (e.g. Cui et al. 2014; Trondman et al. 2015).

Fall Speed of Pollen (FSP) is an important parameter in pollen-vegetation modelling. Between-study differences in FSP for a given taxon will influence the RPP results (e.g. Bunting et al. 2004). However, there is little difference in the estimated FSPs of pollen taxa between this study and other studies in the tropics and subtropics, except for Podocarpus $(0.0175 \mathrm{~m} / \mathrm{s}$ in this study; 0.074 in Hill et al., this volume). Fall speed for Poaceae varies between studies from $0.0133 \mathrm{~m} / \mathrm{s}$ in tropical China (Wan et al. 2020) to $0.050 \mathrm{~m} / \mathrm{s}$ in South Africa (Hill et al., this volume). However, the FSP estimate from the study in Namibia $(0.031 \mathrm{~m} / \mathrm{s}$, Tabares et al. 2021) is close to the FSP we are using $(0.035 \mathrm{~m} / \mathrm{s}$; Broström et al. 2004).

\subsubsection{Comparison with RPPs from other studies in the tropics}

RPP values are available from other studies in the tropics for six taxa included in our study (number of values in brackets, our study excluded): Combretaceae/Melastomataceae (1), Cyperaceae (2), Macaranga (1), Moraceae (3), Podocarpus (1) and Rosaceae (3; for comparison with the RPP of Prunus africana/Rubus pinnatus) (Table 1B). RPPs for each of these taxa are surprisingly similar given that studies are from geographically very different regions and often use different methods. The comparison confirms RPPs smaller than that of Poaceae for Combretaceae/Melastomataceae, Cyperaceae, and Rosaceae, and RPPs larger than that of Poaceae for Macaranga. However, Moraceae exhibit contradicting results with RPPs that are either larger (one value in tropical China) or smaller (two values) than the RPP of Poaceae. Similarly, Podocarpus has a much smaller RPP than Poaceae in our study, but much larger RPP than Poaceae in South Africa (see Hill et al., this volume). Earlier studies have also reported that both Moraceae and Podocarpus can exhibit high and low pollen quantities in surface samples within only a few 
meters (e.g. Gosling et al. 2005; Maley et al. 1990; Vincens 1984; Wan et al. 2020). Moreover, results indicated that Podocarpus pollen \% in surface soils were often high within the forest (up to $40 \%$ in Vincens (1984) or 60\% in Maley et al. (1990)), and decreased abruptly over the forest edge (to $c$. $10 \%$ ) and beyond, to $<5 \%$ already $10 \mathrm{~m}$ from the edge (Maley et al. 1990) or to c. $5 \%$ and $1 \% 10 \mathrm{~km}$ and $50 \mathrm{~km}$ from the edge, respectively (Vincens 1984). Lézine (unpublished) also reported that Podocarpus pollen percentage in soil samples within the Podocarpus forests of Cameroon can vary between very low and high values within a few meters. The very low RPP of Podocarpus obtained in our study is probably due in part to the low proportions of the taxon in the studied forests (c. 8-23\%, max. $29 \%$, in distance-weighted plant abundance within $100 \mathrm{~m}$ of the studied sites) with corresponding pollen percentages of $0.2-2.5 \%$, maximum $8 \%$ for $29 \%$ plant cover. Such 'fuzzy' pollen-vegetation relationships need to be further investigated. New, carefully designed RPP studies are necessary before we can conclude on this issue and the relevance of quantitative reconstruction for this type of taxa. Moreover, the pollen-vegetation relationship of Podocarpus can be biased by long-distance pollen transport, as reported in earlier studies (e.g. Maley et al. 1990; Vincens 1984; Wan et al. 2020).

Earlier studies of modern and fossil pollen spectra and related vegetation provide some hints on whether the RPP we obtained for the remaining six taxa roughly agree with those results in terms of representation of vegetation by pollen. Pollen of several entomophilous tropical taxa have been found in large numbers, e.g. Alchornea (Elenga et al. 2000; Reynaud-Farrera 1995; Vincens et al. 1997, 2000; Watrin et al. 2007), and Celtis and Syzygium (e.g. Verlhac et al. 2018; Watrin et al. 2007). Lézine et al. (2013) suggested that Schefflera might be overrepresented in the pollen record from Bambili due to high pollen productivity and long-distance transport. Our results suggest that these four taxa all have RPPs larger (Schefflera, Syzygium) or much larger (Alchornea, Celtis) than Poaceae (Table 1A).

\subsubsection{LRA reconstructions of Holocene plant cover at regional and local spatial scales}

Although the 11 pollen taxa used in the LRA reconstructions generally represent $>60-70 \%$ of the total pollen sum of terrestrial pollen types in the four pollen records (Table S3A), it is essential to keep in mind that we are missing in many cases a third of the pollen record. Major taxa for which we would need RPP estimates to achieve more complete reconstructions of the plant cover are: Aerva-type, Antidesma-type, A. venosum, Ficus, Gnidia, Justicia, Maesa, and Rapanea (mountain woodlands), and Cussonia, Hymenocardia, Ixora, Olea, Tetrorchidium, and Uapaca (wooded grasslands). One RPP value (19.19 relative to Poaceae) is available for Justicia (Navya 2020). Based on a large database of surface pollen samples in Africa, Gajewski et al. (2002) concluded that Olea pollen (O. capensis-type) represent the presence and abundance of the plant correctly. Uapaca was found to be either over-represented or under-represented by pollen (Julier et al. 2019). The information we have so far on the pollen-vegetation relationships of the taxa mentioned above is still too poor to anticipate the effect they would have on the LRA reconstructions. They could influence (in terms of plant cover) the timing, rate and magnitude of change in the woodland/openland relationship, and the taxa composition in woodlands over time.

We consider that the LRA reconstructions using the lowest RPP (0.06) for Podocarpus are unrealistic. The low RPP results in an extreme dominance of Podocarpus over all other tree taxa, and over Poaceae for most of the Holocene (see also discussion on RPPs above). We therefore focus on the reconstructions performed with the alternative RPPs 2.62 and 6.38, i.e. pollen productivities higher than that of Poaceae. These RPP values are also in a comparable range of values as common entomophilous tree taxa in African pollen records such as Alchornea, Celtis, Schefflera, and Syzygium. 


\subsubsection{Mountain woodlands: Mbi and Bambili}

The assumed minimum size of the landscape represented by REVEALS estimates of plant cover is $100 \mathrm{~km} \times 100 \mathrm{~km}$ (see Methods), which corresponds to an area around the site Mbi covering today montane and submontane vegetation (c. 55\%), Guineo-Congolian rain and semi-deciduous forests (c. 20\%), and secondary forests and grassland (25\%), i.e. vegetation types from altitudes between $c .1000$ and $3000 \mathrm{~m}$ asl. (Figures 1 and 2).

The REVEALS reconstructions suggest a clear dominance of grasses in the regional vegetation over the entire Holocene. The composition of trees is significantly different in plant cover compared to the pollen percentages, with a generally smaller cover than pollen percentage of Schefflera, Podocarpus (high altitude taxa) and Alchornea (low altitude taxon), and larger cover than pollen percentage of Moraceae and Combretaceae/Melastomataceae (mid-altitude taxa) and Poaceae (mainly mid- and low altitude) (see Figure 2 for the altitudinal distribution of taxa). Thus, the REVEALS reconstruction suggests that the regional landscape was much more open than suggested by the pollen percentages, and the high altitude and low altitude trees less abundant in relation to mid altitude trees. However, the REVEALS reconstruction does not alter the overall history and timing of changes in woodland abundance documented by the pollen percentages.

The LOVE reconstructions represent plant cover over a $2 \mathrm{~km}$-radius area (assumed RSAP, Methods and SOM-12.1.4) around the lake of Bambili, which includes essentially afro-alpine grasslands and montane forests. The reconstructions suggest that the vegetation at Bambili was $100 \%$ forested $11-3.5 \mathrm{ka}$ BP with a stronger dominance of the high altitude taxa (including Moraceae; Ficus in Figure 2) over the low altitude taxa than pollen percentages indicate. The sudden decreases in cover of Podocarpus at $7 \mathrm{ka}$ and $3 \mathrm{ka}$ BP are more pronounced than the declines in percentages, and the general collapse of the mountain forest more rapid. The landscape openness (cover of Poaceae) 3-0.5 ka BP is significantly larger than suggested by the pollen percentages.

\subsubsection{The Sudanian and Guineo-Congolian wooded grasslands: Tilla and Mbalang}

The REVEALS reconstructions of Tilla represent the regional plant cover in the Sudanian dry forests with grasslands and shrublands at low altitudes (Figures 1 and 2) and confirm that tree cover was very small all through the Holocene in contrast to Sahel's more tree-rich vegetation over early and Mid-Holocene (Salzmann et al. 2002). However, Combretaceae/Melastomataceae might have been more abundant in relation to Alchornea, Celtis, and Macaranga than pollen percentages suggest.

The assumed RSAP of Lake Mbalang $(2 \mathrm{~km})$ lies within the Sudano-Guinean wooded grasslands. The LOVE reconstruction suggests a $10-15 \%$ higher cover of tree taxa in the vegetation compared to the pollen percentages 6-3 ka BP and confirms a local presence of Podocarpus and Prunus africana/Rubus pinnatus. However, the larger abundance of trees compared to pollen percentages might be a bias due to the pollen record from Tilla representing only the very open regional vegetation North of Mbalang and not the areas West and South of the lake that might have been more wooded. Therefore, the LRA might have substracted too large amounts of Poaceae (background pollen inferred from the REVEALS-based regional vegetation of Tilla). If this is the case, pollen percentage of Poaceae might be closer to the actual vegetation openness at Mbalang than its LOVE-estimated cover indicates. A pollen record from a large lake closer to Mbalang would be more appropriate for a LOVE reconstruction.

\subsection{CONCLUSIONS}

The results from this first attempt at estimating RPP for major taxa of the Holocene vegetation of Cameroon confirm the insights gained earlier from traditional studies of the relationship between 
pollen and vegetation. Alchornea, Celtis, Macaranga, Schefflera, and Syzygium have been found to be overrepresented by pollen (Elenga et al. 2000; Lézine et al. 2013; Reynaud-Farrera 1995; Verlhac et al. 2018; Vincens et al. 1997, 2000; Watrin et al. 2007) and are also the taxa for which the estimated RPP are larger than that of Poaceae. Of the taxa for which RPP values are available from other studies, Combretaceae, Cyperaceae, Macaranga and Prunus africana/Rubus pinnatus exhibit relatively small between-study differences in RPPs. Existing RPP values for both Moraceae and Podocarpus are either lower or higher than that of Poaceae, which corroborates earlier observations on the representation of these taxa in modern pollen samples compared to the plant abundance in the vegetation (e.g. Gosling et al. 2005; Maley et al. 1990; Vincens 1984; Wan et al. 2020).

The major uncertainties of our RPP study are due to the strong effect of non-stationary vegetation in the study region on the calculation of RPPs using the maximum likelihood approach. It implies that the RSAP of the pollen samples (here surface soil) is difficult to identify, and therefore the best RPP values are uncertain. Nevertheless, whatever RSAP we would choose (either a few hundred meters or 3 kilometres), ranking of the RPP values would remain the same and, therefore, the correction of the pollen percentages identical. However, the relative cover/abundance of taxa would probably be influenced. In regions where it might be difficult to find large enough areas of stationary vegetation to estimate RPP of forest taxa in particular, one might test the robustness of the obtained RPPs using other models and calculation approaches that might be less sensitive to non-stationary vegetation (Fang et al. 2020; Tabares et al. 2021). In future work, the use of combined satellite and drone data might help to decrease the amount of field work and increase the consistency of vegetation datasets over large areas around each pollen sample site. The latter would probably improve the performance of models for estimation of RPPs.

The LRA reconstructions in this study provide a first tentative quantification of changes in the Afromontane woodlands and wooded grasslands of Cameroon over the Holocene. The results suggest that the regional landscape in the mountain region was more open than pollen percentages suggest, and that the collapse of the high altitude forests around Bambili at $3 \mathrm{ka} \mathrm{BP}$ was faster and of larger magnitude than indicated by the pollen record. The latter will need to be confirmed by further studies involving a larger number of major taxa characteristic of the Holocene vegetation history of Cameroon. The reconstructions also suggest that the woodlands' taxa composition, at both regional and local scales, is different once the pollen percentages are corrected using the RPP dataset and RPPs 2.62 or 6.38 for Podocarpus. The LRA reconstruction for Mbalang confirms the local occurrence of mountain woodland around the lake in Mid-Holocene. The correction of the pollen percentages indicate a larger cover of Prunus africana/Rubus pinnatus and Moraceae than their pollen percentages. Podocarpus and Moraceae are the most problematic taxa to model with the RPPs currently available. The reconstructions using high RPPs for Podocarpus are the most probable so far. It is not possible, based on this study, to assess the reliability of the available RPPs for Moraceae.

\section{ACKNOWLEDGEMENTS}

This research was supported by the National Research Agency (ANR), France, through the C3A (ANR-09-PEXT-001) and VULPES (ANR-15-MASC-0003) projects and by the Labex L-IPSL. We gratefully acknowledge funds from the CNRS (A.-M. Lézine), and Linnaeus University (Faculty of Health and Life Sciences, Kalmar, Sweden) and the Swedish Strategical Research Area 'ModElling the Regional and Global Ecosystem' (MERGE; http://www.merge.lu.se/) (M.-J. Gaillard, E. Githumbi, F. Li). This study is also a contribution to the Past Global Change (PAGES) project and its working group LandCover 6k (http://pastglobalchanges.org/landcover6k), which in turn received support from the Swiss National Science Foundation, the Swiss Academy of Sciences, the US National Science Foundation, and the Chinese Academy of Sciences. We thank 
U. Salzmann (University of Northumbria, Newcastle) and A. Vincens (CEREGE, France) for sharing their pollen data (Tilla and Mbalang, respectively). All pollen records are archived in the African Pollen Database (APD).

\section{REFERENCES}

Abraham, V., Hicks, S., Svobodová-Svitavská, H., Bozilova, E., Panajiotidis, S., FilipovaMarinova, M., Eldegard Jensen, C., Tonkov, S., Pidek, I. A., Swieta-Musznicka, J., Zimny, M., Kvavadze, E., Filbrandt-Czaja, A., Hättestrand, M., Karlıoglu Kılıç, N., Kosenko, J., Nosova, M., Severova, E., Volkova, O., Hallsdóttir, M., Kalnina, L., Noryskiewicz, A. M., Noryskiewicz, B., Pardoe, H., Christodoulou, A., Koff, T., Fontana, S. L., Alenius, T., Isaksson, E., Seppä, H., Veski, S., Pedziszewska, A., Weiser, M. and Giesecke, T., 2021, Patterns in recent and Holocene pollen influxes across Europe - the Pollen Monitoring Programme Database as a tool for vegetation reconstruction. Biogeosciences, 18(15), 4511-4534. 10.5194/bg-18-4511-2021.

Archer, C.L. and Jacobson, M.Z., 2005, Evaluation of global wind power. Journal of Geophysical Research, 110, article: D12110, 10.1029/2004JD005462.

Barnosky, A., Matzke, N., Tomiya, S., Wogan, G. O. U., Swartz, B., Quental, T. B., Marshall, C., McGuire, J. L., Lindsey, E. L., Maguire, K. C., Mersey, B. and Ferrer, E. A., 2011, Has the Earth's sixth mass extinction already arrived? Nature, 471, pp. 51-57, 10.1038/nature09678.

Bouimetarhan, I., Dupont, L., Reddad, H., Baqloul, A., Lézine, A.-M. and APD contributors this volume, Vegetation history and climate change of Africa: A synthesis of deep-sea pollen records. Vegetation response to millennial- and orbital-scale climate changes: A view from the Ocean. Palaeoecology of Africa, 35, chapter: 22, 10.1201/9781003162766-22.

Broström, A., Sugita, S. and Gaillard M.-J., 2004, Pollen productivity estimates for the reconstruction of past vegetation cover in the cultural landscape of southern Sweden. The Holocene, 14, pp. 368-381, 10.1191/0959683604hl713rp.

Broström, A., Sugita, S., Gaillard, M.-J. and Pilesjö, P., 2005, Estimating the spatial scale of pollen dispersal in the cultural landscape of southern Sweden. The Holocene, 15, pp. 252-262, 10.1191/0959683605hl790rp.

Broström, A., Nielsen, A.B., Gaillard, M.-J., Hjelle, K.L., Mazier, F., Binney, H., Bunting, M.J., Fyfe, R., Duffin, K., Meltsov, V., Poska, A., Räsänen, S., Soepboer, W., von Stedingk, H., Suutari, H. and Sugita, S., 2008, Pollen productivity estimates of key European plant taxa for quantitative reconstruction of past vegetation - a review. Vegetation History and Archaeobotany, 17, 461-478, 10.1007/s00334-008-0148-8.

Bunting MJ, Gaillard MJ, Sugita S, Middleton, R. and Broström, A., 2004, Vegetation structure and pollen source area. The Holocene, 14, pp. 651-660, 10.1191/0959683604hl744rp.

Bunting, M.J., Armitage, R., Binney, H.A. and Waller, M., 2005, Estimates of 'relative pollen productivity' and 'relevant source area of pollen' for major tree taxa in two Norfolk (UK) woodlands. The Holocene, 15, pp. 459-465, 10.1191/0959683605hl821rr.

Bunting, M. J., Farrell, M., Broström, A., Hjelle, K., Mazier, F., Middleton, R., Nielsen, A. B., Rushton, E., Shaw, H. and Twiddle, C. L., 2013, Palynological perspectives on vegetation survey: A critical step for model-based reconstruction of Quaternary land cover. Quaternary Science Reviews, 82, pp. 41-55, 10.1016/j.quascirev.2013.10.006.

Chen, H., Xu, Q., Zhang, S., Sun, Y., Wang, M. and Zhou, Z., 2019, Relative pollen productivity estimates of subtropical evergreen and deciduous braodleaved mixed forest in Ta-pieh Mountains. Quaternary Sciences, 39, pp. 469-482, 10.11928/j.issn.1001-7410.2019.02.19.

Cui, Q.Y., Gaillard, M.-J., Lemdahl, G., Stenberg, L., Sugita, S. and Zernova, G., 2014, Historical land-use and landscape change in southern Sweden and implications for present and future biodiversity. Ecology and Evolution, 4, pp. 555-3, 10.1002/ece3.1198,570. 
Duffin, K.I. and Bunting, M.J., 2008, Relative pollen productivity and fall speed estimates for southern African savanna taxa. Vegetation History and Archaeobotany, 17, pp. 507-525, 10.1007/s00334-007-0101-2.

Duthie, T. J., 2015, Relative pollen productivity estimates (PPE) and relevant source area of pollen (RSAP) for key taxa from vegetation communities in Cathedral Peak, KwaZulu-Natal Drakensburg. MSc Thesis, Univ. of KwaZulu-Natal.

Elenga, H., Namur, C.D, Vincens, A., Roux, M. and Schwartz, D., 2000, Use of plots to define pollen-vegetation relationships in densely forested ecosystems of Tropical Africa. Review of Palaeobotany and Palynology, 112, pp. 79-96, 10.1016/S0034-6667(00)00036-1.

Fang, Y., Ma, C. and Bunting, M J., 2019, Novel methods of estimating relative pollen productivity: A key parameter for reconstruction of past land cover from pollen records. Progress in Physical Geography, 46, pp. 731-753, 10.1177/0309133319861808.

Gaillard, M.-J., Sugita, S., Bunting, M.J., Middleton, R., Broström, A., Caseldine, C., Giesecke, T., Hellman, S. E. V., Hicks, S., Hjelle, K., Langdon, C., Nielsen, A. B., Poska, A., von Stedingk, H., Veski, S. and POLLANDCAL members, 2008, The use of modelling and simulation approach in reconstructing past landscapes from fossil pollen data: A review and results from the POLLANDCAL network. Vegetation History and Archaeobotany, 17, pp. 419-443, 10.1007/s00334-008-0169-3.

Gaillard, M.-J., Sugita, S., Mazier, F., Trondman, A.-K., Broström, A., Hickler, T., Kjellström, E., Punes, P., Lemmen, C., Olofsson, J., Smith, B., Strandberg, G., Kokfelt, Ulla., Miller, P., Poska, A., Rundgren, M. and Barnekow, L., 2010, Holocene land-cover reconstructions for studies on landcover-climate feedbacks. Climate of the Past, 6, pp. 483-499, 10.5194/cp-6-483-2010.

Gajewski, K., Lézine, A.-M., Vincens, A., Delestan, A., Sawada, M. and APD members, 2002, Modern climate-vegetation-pollen relations in Africa and adjacent areas. Quaternary Science Reviews, 21, pp. 1611-1631, 10.1016/S0277-3791(01)00152-4.

Gosling, W.D., Mayle, F.E., Tate, N.J. and Killeen, T., 2005, Modern pollen-rain characteristics of tall terra firme moist evergreen forest, southern Amazonia. Quaternary Research, 64, pp. 284-297, 10.1016/j.yqres.2005.08.008.

Grassi, S., Veronesi, F., Schenkel, R., Peier, C., Neukom, J., Volkwein, S., Raubal, M. and Hurni, N., 2015, Mapping of the global wind energy potential using open source GIS data. 2nd International Conference on Energy and Environment: bringing together Engineering and Economics. Guimarães, Portugal 18-19 June, 2015.

Haselhorst, D.S., Moreno, J.E. and Punyasena, S.W., 2013, Variability within the 10-year pollen rain of a seasonal neotropical forest and its implications for paleoenvironmental and phenological research. PLoS One, 8, article: e53485, 10.1371/journal.pone.0053485.

Havinga, A.J., 1984, A 20-year experimental investigation into the differential corrosion susceptibility of pollen and spores in various soil types. Pollen et Spores, 26, pp. 541-558.

Hellman, S., Gaillard, M.-J., Broström, A. and Sugita, S., 2008, The REVEALS model, a new tool to estimate past regional plant abundance from pollen data in large lakes: validation in southern Sweden.Journal of Quaternary Science, 23, pp. 21-42, 10.1002/jqs.1126.

Hellman, S., Bunting, M. J. and Gaillard, M. J., 2009a, Relevant Source Area of Pollen in patchy cultural landscapes and signals of anthropogenic landscape disturbance in the pollen record: a simulation approach. Review of Palaeobotany and Palynology, 153, pp. 245-258, 10.1016/j.revpalbo.2008.08.006.

Hellman, S., Gaillard, M.-J., Bunting, J. M. and Mazier, F., 2009b, Estimating the relevant source area of pollen in the past cultural landscapes of southern Sweden - a forward modelling approach. Review of Palaeobotany and Palynology, 153, pp. 259-271, 10.1016/j.revpalbo.2008.08.008.

Hély, C., Lézine, A.-M. and APD contributors, 2014, Holocene changes in African vegetation: tradeoff between climate and water availability. Climate of the Past, 10, pp. 681-686, 10.5194/cp-10-681-2014. 
Hill, T. R., Duthie, T.J., and Bunting, M.J., this volume, Relevant source area of pollen and pollen productivity estimates from KwaZulu-Natal. Palaeoecology of Africa, 35, chapter: 16, 10.1201/9781003162766-16.

Jiang, F., Xu, Q., Zhang, S., Li, F., Zhang, K., Wang, M., Shen, W., Sun, Y. and Zhou, Z., 2020, Relative pollen productivities of the major plant taxa of subtropical evergreen-deciduous mixed woodland in China. Journal of Quaternary Science, 35, pp. 526-538, 10.1002/jqs.3197.

Julier, A.C.M., Jardine, P. E., Adu-Bredu, S., Coe, A. L., Fraser, W. T., Lomax, B. H., Malhi, Y., Moore, S. and Gosling, W. D., 2019, Variability in modern pollen rain from moist and wet tropical forest plots in Ghana, West Africa. Grana, 58, pp. 45-62, 10.1080/00173134.2018. 1510027.

Kaplan, J.O., Krumhardt, K.M., Gaillard, M.-J., Sugita, S., Trondman, A.-K., Fyfe, R., Marquer, L., Mazier, F. and Nielsen, A.B., 2017, Constraining the deforestation history of Europe: evaluation of historical land use scenarios with pollen-based land cover reconstructions. Land, 6, article: 91, 10.3390/land6040091.

Kuparinen, A., 2006, Mechanistic models for wind dispersal. Trends in Plant Science, 11, pp. 296-301, 10.1016/j.tplants.2006.04.006.

Kuparinen, A., Markkanen, T., Riikonen, H. and Vesala, T., 2007, Modeling air-mediated dispersal of spores, pollen and seeds in forested areas. Ecological Modelling, 208, pp. 177-188, 10.1016/j.ecolmodel.2007.05.023.

Letouzey, R., 1985, Notice de la carte phytogeographique du Cameroun au 1: 500,000, (Toulouse: Institut de la carte internationale de la végétation).

Lézine, A.-M., Assi-Kaudjhis, C., Roche, E., Vincens, A. and Achoundong, G., 2013, Towards an understanding of West African montane forest response to climate change. Journal of Biogeography, 40, pp. 183-196, 10.1111/j.1365-2699.2012.02770.x.

Lézine, A.-M., Lemonnier, K., Waller, M.P., Bouimetarhan, I. and Dupont, L., this volume, Changes in the West African landscape at the end of the African Humid Period Palaeoecology of Africa, 35, chapter: 6, 10.1201/9781003162766-6.

Lézine, A-M., Izumi, K. and Achoundong, G., 2021, Mbi Crater (Cameroon) illustrates the relations between mountain and lowland forests over the past 15,000 years in western equatorial Africa. Quaternary International. DOI: 10.1016/j.quaint.2020.12.014.

Li, F.-R., Gaillard, M.-J., Sugita, S., Mazier, F., Xu, Q.-H., Zhou, Z.-Z., Zhang, Y., Li, Y. and Laffly, D., 2017, Relative pollen productivity estimates for major plant taxa of cultural landscapes in central eastern China. Vegetation History and Archaeobotany, 26, pp. 587-605, 10.1007/s00334-017-0636-9.

Li, F., Gaillard, M.-J., Cao, X., Herzschuh, U., Sugita, S., Tarasov, P.-E., Wagner, M., Xu, Q., Ni, J., Wang, W., Zhao, Y., An, C., Beusen, A.H.W., Chen, F., Feng, Z., Klein Goldewijk, C.G.M., Huang, X., Li, Y., Li, Y., Liu, H., Sun, A., Yao, Y., Zheng, Z. and Jia, X., 2020, Towards quantification of Holocene anthropogenic land-cover change in temperate China: A review in the light of pollen-based REVEALS reconstructions of regional plant cover, Earth-Science Reviews, 203, article 103119, 10.1016/j.earscirev.2020.103119.

Lu, Z., Miller, P.A., Zhang, Q., Zhang, Q., Warlind, D., Nieradzik, L., Sjolte, J. and Smith, B., 2018, Dynamic vegetation simulations of the mid-Holocene green Sahara. Geophysical Research Letters 45, pp. 8294-8303, 10.1029/2018GL079195.

Maley, J. Caballe, G. and Sita, P., 1990, Etude d'un peuplement résiduel à basse altitude de Podocarpus latifolius sur le flanc congolais du massif du Chaillu. Implications paléoclimatique et biogéographiques. Etude de la pluie pollinique actuelle. In : Paysages Quaternaires de 1'Afrique Centrale Atlantique, edited by Lanfranchi R. and Schwartz D., Paysages quaternaires de l'Afrique centrale atlantique, pp. 336-352 (Paris : ORSTOM).

Masson-Delmotte, V., Schulz, M., Abe-Ouchi, A., Beer, J., Ganopolski, A., Gonzaalez Rouco, J.F., Jansen, E., Lambeck, K., Luterbacher, J., Naish, T., Osborn, T., Otto-Bliesner, B., Quinn, 
T., Ramesh, R., Rojas, M., Shao, X. and Timmermann, A., 2013, Information from paleoclimate archives. In Climate Change 2013: the Physical Science Basis. Contribution of Working Group I to the Fifth Assessment Report of the Intergovernmental Panel on Climate Change, edited by Stocker, T.F., Qin, D., Plattner, G.-K., Tignor, M., Allen, S.K., Boschung, J., Nauels, A., Xia, Y., Bex, V. and Midgley, P.M. pp. 383-464 (Cambridge University Press).

Mazier, F., Gaillard, M. J., Kuneš, P., Sugita, S., Trondman, A. K. and Broström, A., 2012, Testing the effect of site selection and parameter setting on REVEALS-model estimates of plant abundance using the Czech Quaternary Palynological Database. Review of Palaeobotany and Palynology, 187, pp. 38-49, 10.1016/j.revpalbo.2012.07.017.

Navya R., 2020, Pollen based estimates of Holocene vegetation in southern India: An LRA (Landcover Reconstruction Algorithm) approach ", PhD Thesis, Pondicherry University, Puducherry, India, pp. 1-268.

Parsons, R.W. and Prentice, I.C., 1981, Statistical approaches to R-values and the pollenvegetation relationship. Review of Palaeobotany and Palynology, 32, pp. 127-152, 10.1016/0034-6667(81)90001-4.

Piraquive Bermúdez, D., Theuerkauf, M. and Giesecke, T., 2019, Towards quantifying Holocene changes in forest cover in the Araucaria forest grassland mosaic of southern Brazil. Abstract. 20th Congress of the International Union for Quaternary Research (INQUA), Dublin 25-31 July 2019, https://app.oxfordabstracts.com/events/574/program-app/submission/92213.

Prentice, I.C., 1985, Pollen representation, source area, and basin size - toward a unified theory of pollen analysis. Quaternary Research, 23, pp. 76-86, 10.1016/0033-5894(85)90073-0.

Prentice, I.C. and Parsons, R.W., 1983, Maximum likelihood linear calibration of pollen spectra in terms of forest composition, Biometrics, 39, pp. 1051-1057, 10.2307/2531338.

Prentice, I.C. and Webb III, T., 1986, Pollen percentages, tree abundances and the Fagerlind effect. Journal of Quaternary Science, 1, pp. 35-43, 10.1002/jqs.3390010105.

Reynaud-Farrera, I., 1995, Histoire des paléoenvironnements forestiers du sud Cameroun à partir d'analyses palynologiques et statistiques de dépôts holocènes et actuels. $\mathrm{PhD}$ Thesis, University of Montpellier, France.

Salzmann, U., Hoelzmann, P. and Morczinek, I., 2002, Late Quaternary climate and vegetation of the Sudanian zone of northeast Nigeria. Quaternary Research, 58, pp. 73-83, 10.1006/qres.2002.2356.

Sugita, S., 1994, Pollen representation of vegetation in Quaternary sediment: theory and method in patchy vegetation. Ecology, 82, pp. 881-897, 10.2307/2261452.

Sugita, S., 2007a, Theory of quantitative reconstruction of vegetation I: pollenfrom large sites REVEALS regional vegetation composition. The Holocene, 17, pp. 229-241, $10.1177 / 0959683607075837$.

Sugita, S., 2007b, Theory of quantitative reconstruction of vegetation II: all you need is LOVE. The Holocene, 17, pp. 243-257, 10.1177/0959683607075838.

Tabares, X., Ratzmann, G., Kruse, S., Theuerkauf, M., Mapani, B. and Herzschuh, U., 2021, Relative pollen productivity estimates of savanna taxa from southern Africa and their application to reconstruct shrub encroachment during the last century. The Holocene.

Theuerkauf, M., Kuparinen, A. and Joosten, H., 2013, Pollen productivity estimates strongly depend on assumed pollen dispersal. The Holocene, 23, pp. 14-24, $10.1177 / 0959683612450194$.

Trondman, A. K., Gaillard, M.-J., Mazier, F., Sugita, S., Fyfe, R., Nielsen, A. B., Twiddle, C., Barratt, P., Birks, H. J. B., Bjune, A. E., Bjorkman, L., Broström, Anna. Caseldine, C., David, R., Dodson, J., Doerfler, W., Fischer, E., van Geel, B., Giesecke, T., Hultberg, T., Kalnina, L., Kangur, M., van der Knaap, P., Koff, T., Kunes, P., Lageras, P., Latalowa, M., Lechterbeck, J., Leroyer, C., Leydet, M., Lindbladh, M., Marquer, L., Mitchell, F. J. G., Odgaard, B. V., Peglar, S. M., Persson, T., Poska, A., Roesch, M., Seppa, H., Veski, S. and Wick, L., 2015, Pollenbased quantitative reconstructions of Holocene regional vegetation cover (plant-functional 
types and land-cover types) in Europe suitable for climate modelling. Global Change Biology, 21, pp. 676-697.

Verlhac, L., Izumi K., Lézine, A.-M., Lemonnier, K., Buchet, G., Achoundong, G. and Tchiengué, B., 2018, Altitudinal distribution of pollen, plants and biomes in the Cameroon highlands. Review of Palaeobotany and Palynology, 259, pp. 21-28, 10.1016/j.revpalbo.2018.09.011.

Vincens, A., 1984, Environnement végétal et sédimentation pollinique lacustre actuelle dans le Bassin du Lac Turkana (Kenya). Revue de Paléobiologie, volume spécial, 1, pp. 235-242.

Vincens, A., Ssemmanda, I., Roux, M. and Jolly, D., 1997, Study of the modern pollen rain in western Uganda with a numerical approach. Review of Palaeobotany and Palynology, 96, pp. 145-168, 10.1016/S0034-6667(96)00022-X.

Vincens, A., Schwartz, D., Elenga, H., Reynaud-Farrera, I., Alexandre, A., Bertaux, J., Mariotti, A., M., Meunier, J.D., Nguetsop, F., Servant, M., Servant-Vildary, S. and Wirrmann, D., 1999, Forest response to climate changes in Atlantic Equatorial Africa during the last 4000 years BP and inheritance on the modern landscapes. Journal of Biogeography, 26, pp. 879-885, 10.1046/j.1365-2699.1999.00333.x.

Vincens, A., Dubois, M.A., Guillet, B., Achoundong, G., Buchet, G., Kamgang Kabeyene Beyala, V., de Namur, C. and Riera, B., 2000, Pollen-rain-vegetation relationships along a forest- savanna transect in southeastern Cameroon. Review of Palaeobotany and Palynology, 110, pp. 191-208, 10.1016/S0034-6667(00)00009-9.

Vincens, A., Lézine, A.M., Buchet, G., Lewden, D. and Le Thomas, A., 2007, African pollen database inventory of tree and shrub pollen types. Review of Palaeobotany and Palynology, 145, pp. 135-141, 10.1016/j.revpalbo.2006.09.004.

Vincens, A., Buchet, G., Servant, M. and ECOFIT Mbalang collaborators, 2010, Vegetation response to the "African Humid Period" termination in Central Cameroon $\left(7^{\circ} \mathrm{N}\right)$ - new pollen insight from Lake Mbalang. Climate of the Past, 6, pp. 281-294, 10.5194/cp-6-281-2010.

Wan, Q., Zhang, Y., Huang, K., Sun, Q., Zhang, X., Gaillard, M.-J., Xu, Q., Li, F. and Zheng, Z., 2020, Evaluating quantitative pollen representation of vegetation in the tropics: A case study on the Hainan Island, tropical China. Ecological Indicators, 114, article: 106297, 10.1016/j.ecolind.2020.106297.

Watrin, J., Lézine, A.-M., Gajewski, K. and Vincens, A., 2007, Pollen plant-climate relationships in sub-Saharan Africa. Journal of Biogeography, 34, pp. 489-499, 10.1111/j.13652699.2006.01626.x.

White, F., 1983, The vegetation of Africa. (Paris: UNESCO).

Whitney, B.S., Smallman, T.L., Mitchard, E.T., Carson, J.F., Mayle, F.E., and Bunting, M.J., 2018, Constraining pollen-based estimates of forest cover in the Amazon: a simulation approach. The Holocene, 29, pp. 262-269, 10.1177/0959683618810394.

Wieczorek, X. and Herzschuh, U., 2020, Compilation of relative pollen productivity (RPP) estimates and taxonomically harmonised RPP datasets for single continents and Northern Hemisphere extratropics. Earth System Science. Data, 12, 3515-3528, 10.5194/essd-12-35152020.

Zhang, S.-R., Xu, Q.-H., Gaillard, M.-J., Cao, X.-Y., Li, J., Zhang, L., Li, Y., Tian, F., Zhou, L., Lin, F., and Yang, X., 2016, Characteristic pollen source area and vertical pollen dispersal and deposition in a mixed coniferous and deciduous broad-leaved woodland in the Changbai mountains, northeast China. Vegetetation History and Archaeobotany, 25, pp. 29-43, 10.1007/s00334-015-0532-0. 


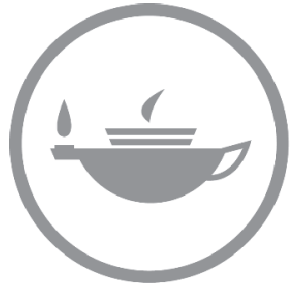

Taylor \& Francis Taylor \& Francis Group http://taylorandfrancis.com 